\title{
The Impact of Perceived Social Responsibility on Emotional Commitment Based on the Mediating Role of Employee-Organization Compatibility, Organizational Identity and Perceived Organizational Support
}

Nima Ranji Jafroodi' ${ }^{1}$ Assistant Professor, Department of Public Administration, Islamic Azad University, Bandar-e-Anzali Branch, Iran. (Corresponding Author)

Pedram Nasrollahi Moghaddam M.A. in Public Administration, Islamic Azad University, Bandar-e-Anzali Branch, Iran.

\begin{abstract}
Capable human resources are highly important because they are rare and irreplaceable. Hence, organizations do their best to maintain the skillful members and to improve their commitment. The purpose of this article is to study the impact of perceived social responsibility on emotional commitment on the basis of mediating role of employeeorganization compatibility, organizational identity and perceived organizational support. Data were collected from a sample size of 177 employees of Anzali Port Free Zone Organization and the structural equations method was applied to analyze the acquired data. Results show that the impact of perceived social responsibility on perceived employee-organization compatibility is positively significant. The same is true with the impact of employee-organization compatibility on organizational identity and perceived organizational support. Moreover, findings show that organizational identity and perceived organizational support have positive and significant impact on employees' emotional commitment. Finally, the impact of organizational identity and perceived organizational support as a mediating variable between employee-organization compatibility and employees' emotional commitment is positively significant.
\end{abstract}

Keywords: Emotional Commitment, Social Responsibility, EmployeeOrganization Compatibility, Organizational Identity Perceived Organizational Support. 
عنوان مقاله: تاثير مسئوليت اجتماعى دركشده بر تعهد

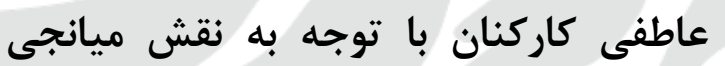

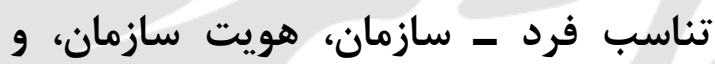
حمايت سازمانى ادراكشده نيما رنجى جفرودى' - يدرام نصر اللهىىمقدم'

\section{مقاله بثوهشى}

\section{جكيده:}

منابع انسانى كارامد به دليل كميابى و جانشين نايذيرى اهميت بسيارى دارد، از اينرو

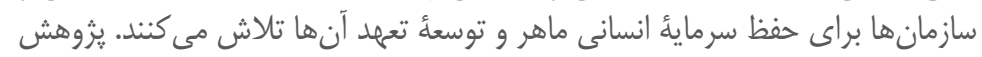

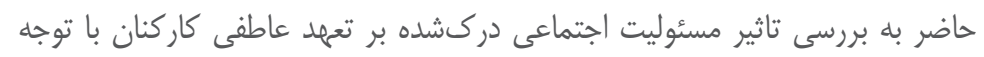

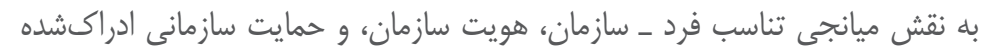

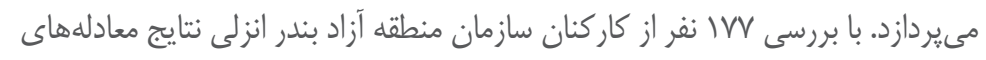

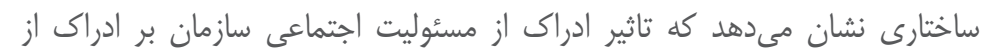

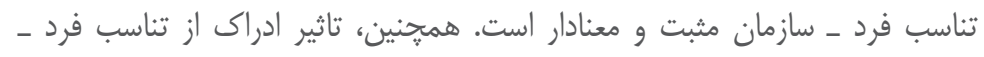

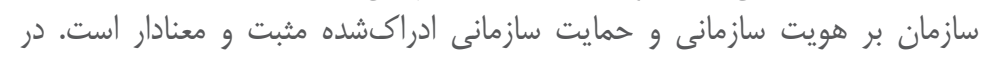

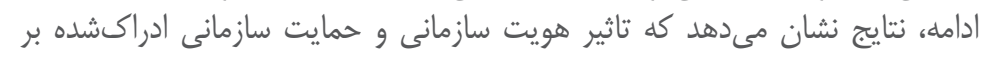

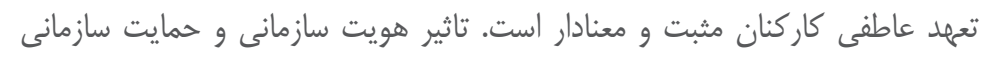

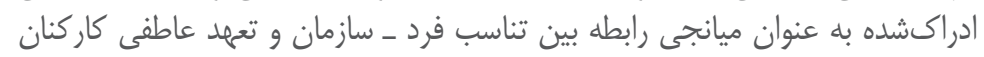

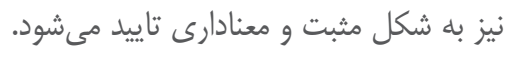

كليلوازهها: تعهل عاطفى، مسئوليت اجتماعى، تناسب فرد ـ سازمان،

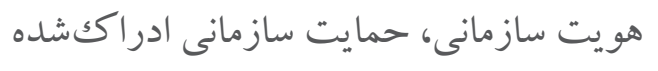
ranji@iaubanz.ac.ir

1. استاديار گروه مديريت دولتى، واحدبندرانزلى، دانشگاه آزاد اسلامى،بندرانزلى، ايران. (نويسنده مسئول) 2 r. كارشناسى ارشد مديريت دولتى، واحدبندرانزلى، دانشخاه آزاد اسلامى، بندرانزلى، ايران. 


\section{مقدمه}

ادراك و نخَرش در طول زندگى سازمانى كاركنان داراى اهميت است. يكى از نخرشهاى محورى يزوهشهاى سازمانى، تعهد است كه به عنوان ييوند روانشناختى بين كاركنان و سازمان تعريف مىشود، و احتمال اين كه كاركنان بلطور ارادى سازمان را ترك كنند كاهش مىدهد (كاظمى

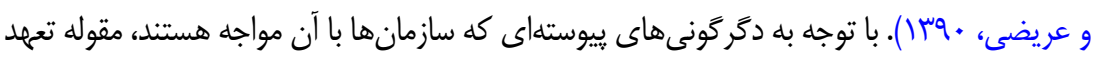

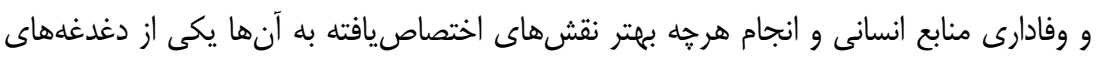
جدى مديران است (ناصحىفر و محمدخانى، هوس ا). تعهد عاطفى كه تعلق احساسى فرد به سازمان است، مفهوم مهمى براى درى وفادارى به سازمان و از خودكذشتخى كاركنان براى سازمان است. تعهلد عاطفى مهمترين بعد تعهد سازمانى براى بيشبينى رفتارهاى شغلى، غيبت، و قصد ترى

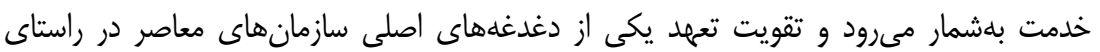
حفظ كاركنان بااستعداد در اقتصادهاى دانشمحور است (تابلى و همكاران، سوسا ). يكى از راههاى ايجاد تعهد عاطفى و احساسى در كاركنان نسبت به سازمان مسئوليت اجتماعى است كه مىتواند ييامدهاى مثبت فراوانى داشته باشد. در سالهاى اخير، تاكيد فزايندهاى بر اهميت مفهوم مسئوليت

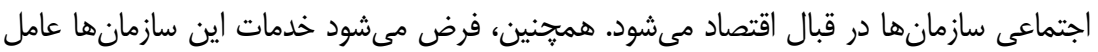
ايجاد منافع در محيط رقابتى است كه در بر گيرنده اهداف زيستمحيطى، اقتصادى، و اجتماعى است (Gallardo-Vázquez \& Sanchez-Hernandez, 2014)

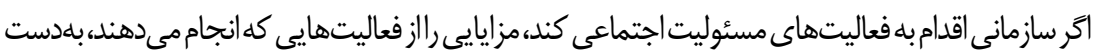

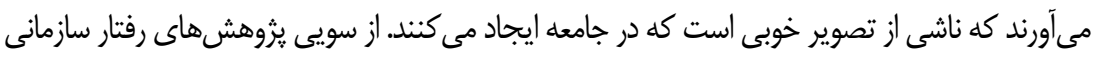
در دو دهأ كذشته، تمايل قابلتوجهى به سمت هويت سازمانى داشته است (Riketta, 2005). زيرا هويت

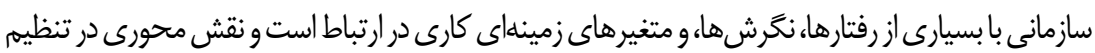
هنجارهاى رفتارى اعضاى سازمان ايفا مى كند و باعث بلوجود آمدن خودتنظيمى نزد افراد براى دستيابى به اهداف عملكردى در سازمان مىشود. مديران همواره به دنبال ارزيابى و ارتقاى هويت سازمانى در ميان كاركنان خود هستند، زيرابه نتايج مثبت آن علاقهمند هستند. تازمانى كه كاركنان سازمان احساس هويت

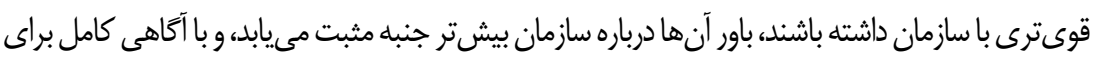
تحقق اهداف سازمان تلاش مى كنند و تعملد بالاترى به سازمان خود دارند (قاسمزاده و همكاران، سوسا ). 
در اين يزوهش، تاثير سه عامل تناسب فرد ـ سازمان، حمايت سازمانى ادراكشده، و هويت

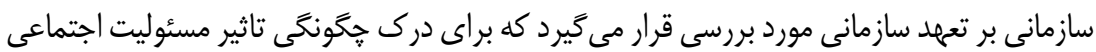

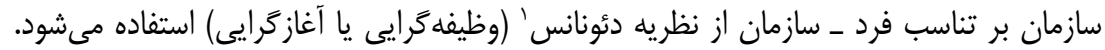
بر اساس اين ديدكاه، هر عمل به نتيجة آن بستخى ندارد، بلكه به نيت شخص تصميهم

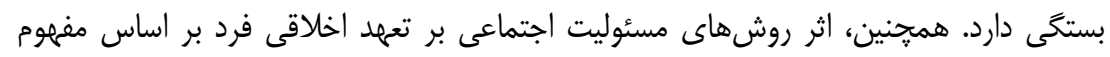

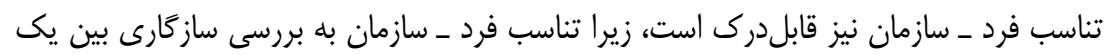

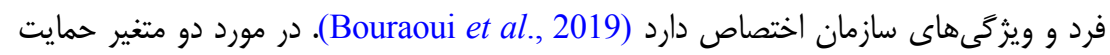
سازمانى ادراكشده و هويت سازمانى نيز مىتوان كفت كه حمايت سازمانى ادراكشده كيفيت إداص

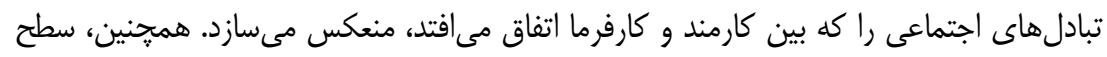
بالاى حمايتهاى سازمانى ادراكشده موجب ايجاد تعهد در كار كنان به منظور جبران إندان اين امتيازها

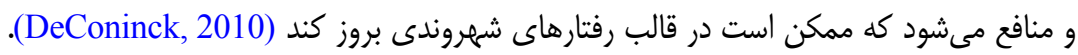

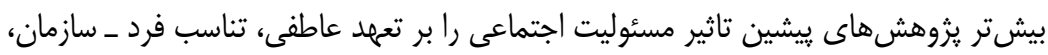

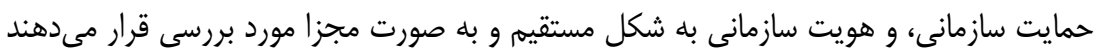
Cheema et al., 2020; Farooq et al., 2017; Ahmad et al., 2020; Bouraoui et al.,) 2019; Story \& Castanheira, 2019$)$ برخى ثروهشها هم به تاثير مسئوليت اجتماعى بر تعهد

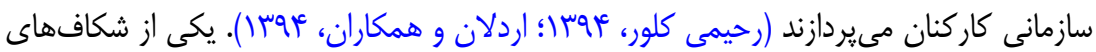
عمده بزوهشهاى ييشين نبود سازوكارهاى اساسى در توضيح رابطه مسئوليت اجتماعى دركشدها

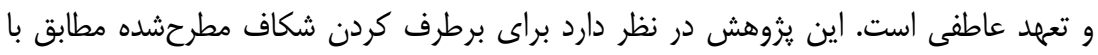

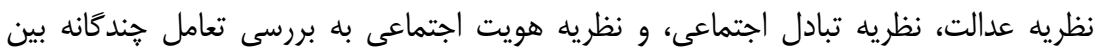

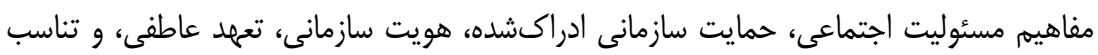

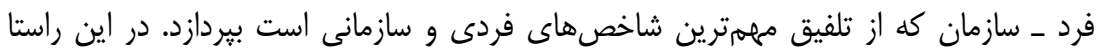

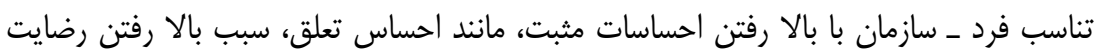

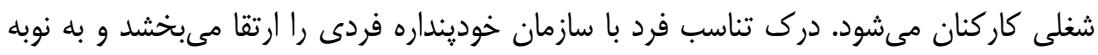

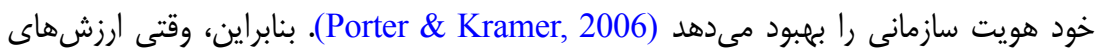

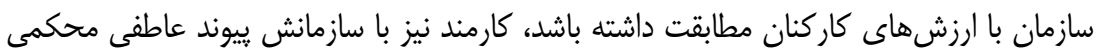

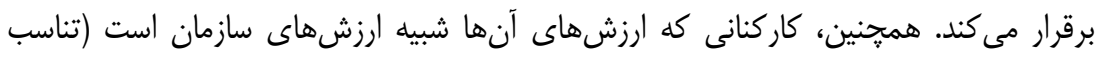

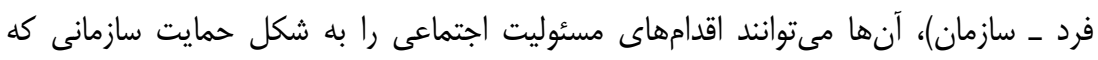

1. Deonance 
نيازهاى اساسى را برآورده مى كند، مهم تلقى كنند. علاوه بر اين، سازمانى كه با ذيىنفعان مختلف

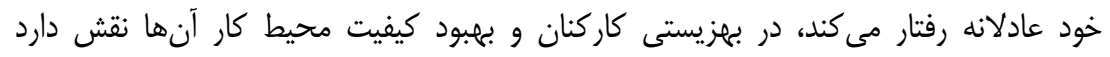

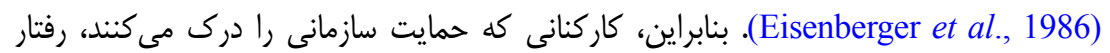
مثبت دريافتشده را با تعهد سازمانى بيشتر جبران مى كنند. شكاف ديگرى كه در يزوهشهاى

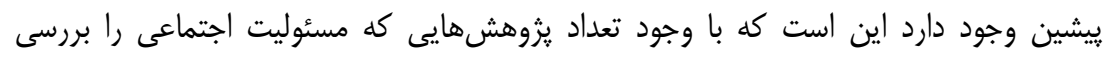
مىنمايند، يزوهشهاى كمى بر سياستهاى مسئوليت اجتماعى بر نكرش و رفتار كاركنان در

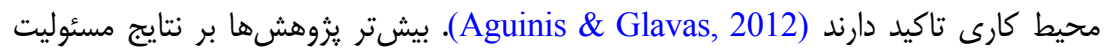

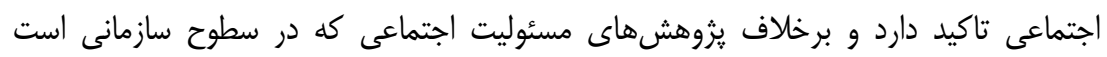

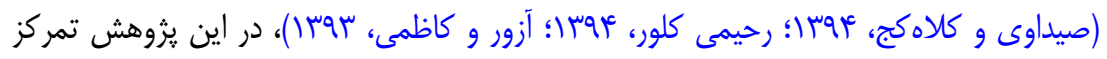

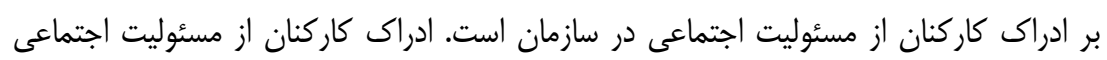

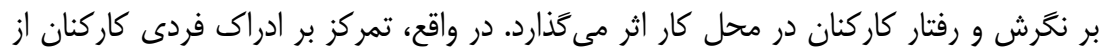

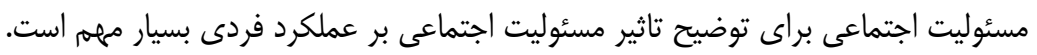

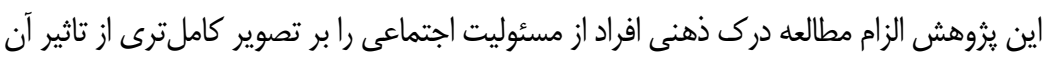

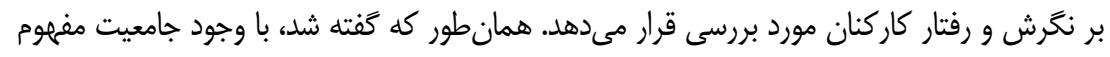
مسئوليتيذيرى اجتماعى و تعهد عاطفى، بزوهشى در خصوص تاثير گذارى اين متغيرها بر يكديخر از

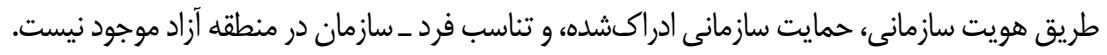

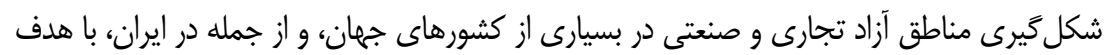

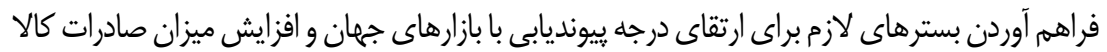

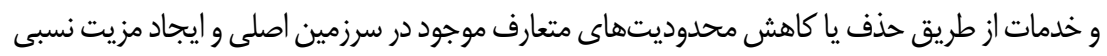

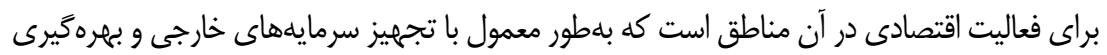

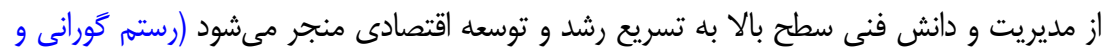

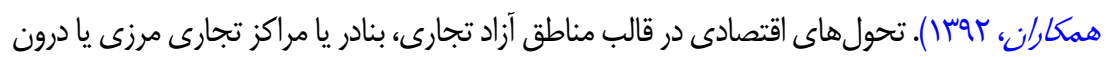
كشور كه محل تجمع كروههاى انسانى است، تغيير و تحولاتى رابا خود در زيست انسانى و مسائل مرتبط

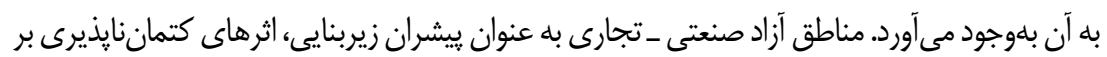

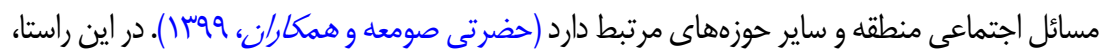

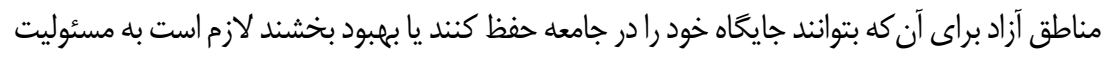

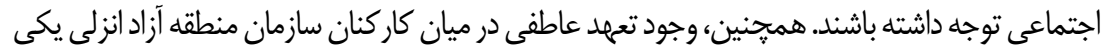

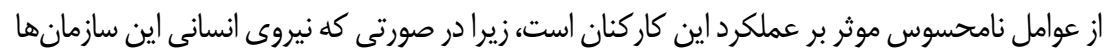


وفادار، متعهد، و سازكار با اهداف و اززشهاى سازمانى باشند، مىتوانند حتى فراتر از وظايف مقرر در

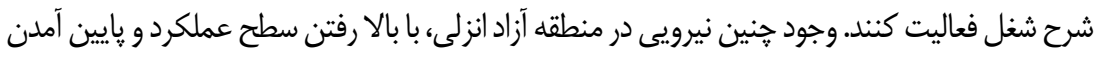

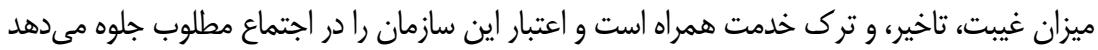

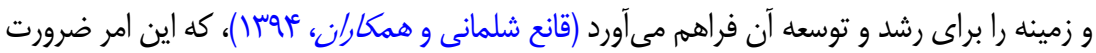

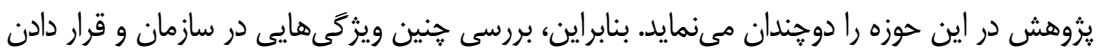

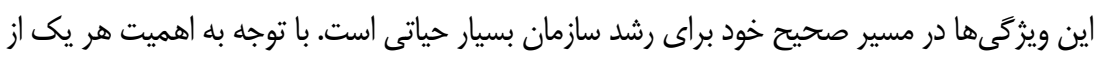

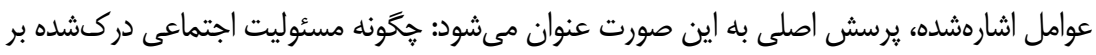
تعهد عاطفى كاركنان با توجه به نقش ميانجى تناسب فرد ـ سازمان، هويت سازمان، و حمايت سازمانى

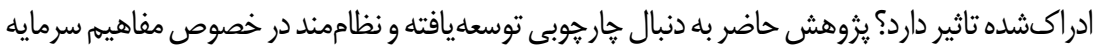

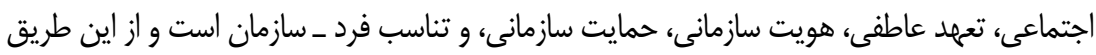

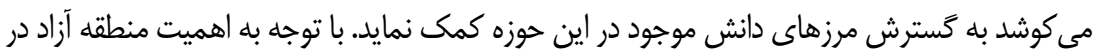

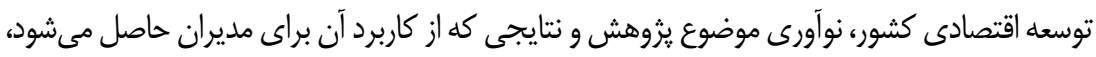
ضرورت انجام يزوهش را مشخص مىنمايد.

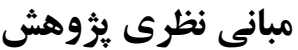

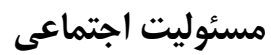

مسئوليت اجتماعى سازمانها يكى از برنامههاى راهبردى در مورد سود و مزاياى بايدار

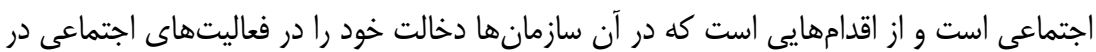

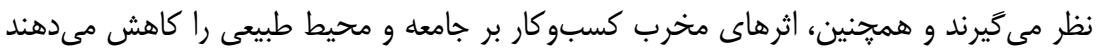

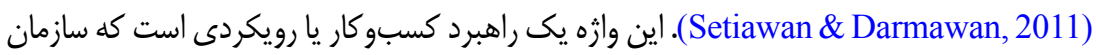
را به شيواى مسئولانه بر اساس وضعيت و موجوديت سازمان به عنوان يك ابزار و محركى براى

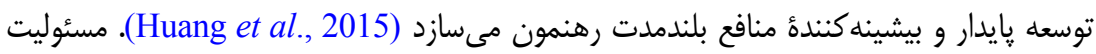
اجتماعى سازمان به بخش مهمى از فعاليتهاى روابط عمومى سازمانها و همجنين به يكى بهان يارامتر رقابتى تبديل شده است، زيرا كيفيت و قيمت هميشه براى ساخت محصولات دلخواه

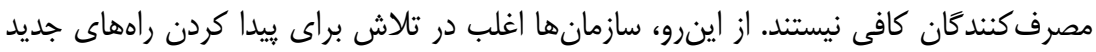
براى تمايز محصولات و خدمات خود هستند. اينجاست كه مسئوليت اجتماعى سازمان مىتواند

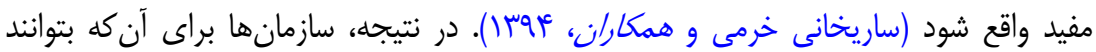


جايكاه خود را در جامعه حفظ كنند يا بببود بخشند، بهنحوى كه باعث ادامه بقا و موفقيتشان در كار شود، لازم است به مسئوليت اجتماعى توجه داشته باشند (صيداوى و كلاهكج، أوجسار).

\section{تناسب فرد با سازمان}

تناسب فرد ـ سازمان يك بخش از مفهوم گستردهتر تناسب فرد ـ محيط است كه از نظر

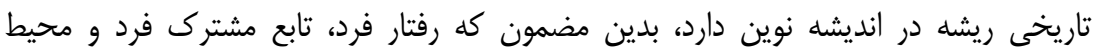

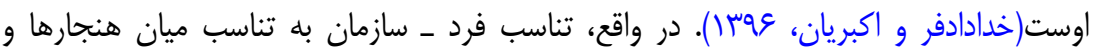

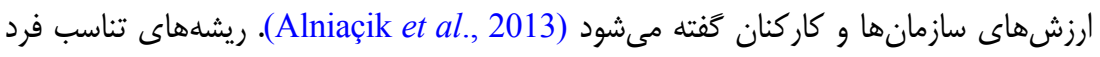
ـ سازمان به خارجوب جذب انتخاب ـ اخراج اشنايدر' (19AV) برمى گردد. اشنايدر (19AV)، بيان

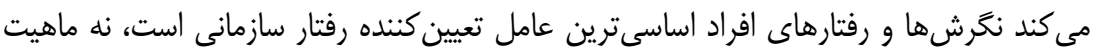
محيط بيرونى و فناورى سازمان يا ساختار سازمانى. سازمانها داراى شخصيت منحصربهافردى

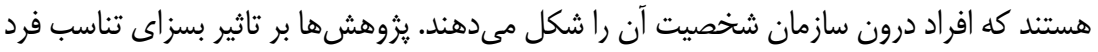

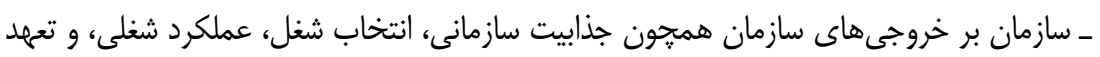

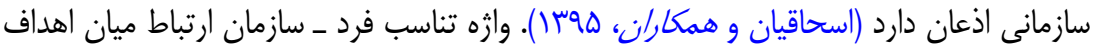

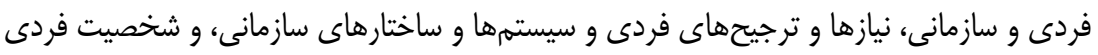

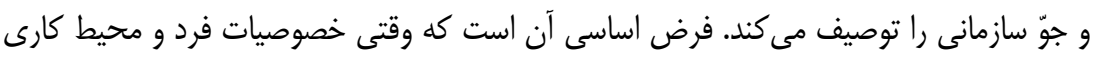
اطرافش با هم تطابق دارند، يا دست كم همخوانى بالايى داشته باشند، اثربخشى افزايش مى ائلد

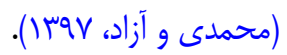

\section{هويت سازمانى}

در دهأ •l9V هويت سازمانى به عنوان مولفهاى از تعهد نكرشى (عاطفى و روانى) تعريف

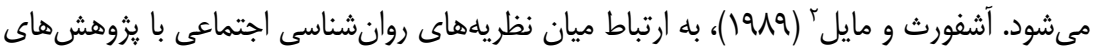

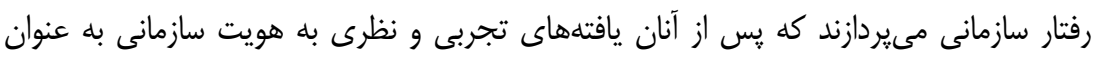
مولفههايى جداكانه مىنگرند. در همان زمان، به تعريف هويت سازمانى با استفاده از هويت اجتماعى نانى

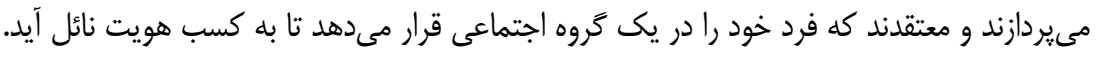

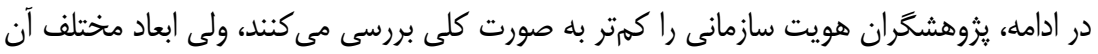


را مورد بررسى قرار مىدهند و ارتباط آن را با ساير متغيرهاى سازمانى مىسنجند (هيبت الهيور و

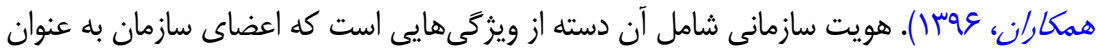

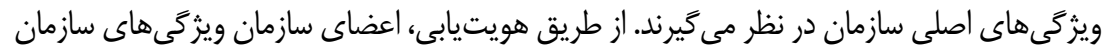

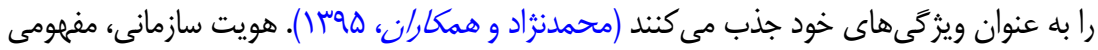

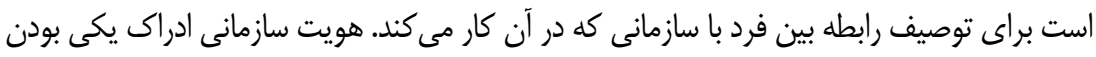
با سازمان است در جايى كه افراد خود را بر اساس خصوصيات سازمانشان تعريف مى كنند (محمدزاده و همكاران، كوسا). تازمانى كه كار كنان سازمان احساس هويت قوى دترى با سازمان داشته باشند، باور

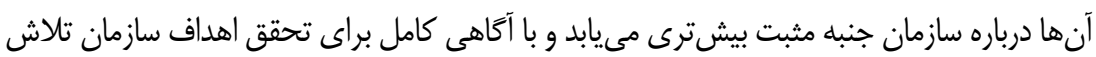

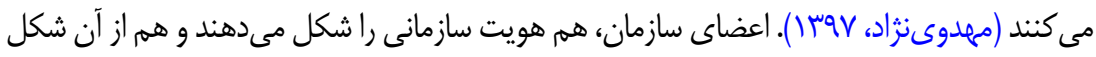

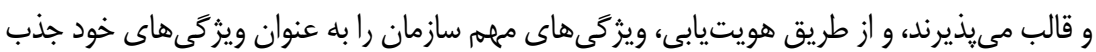

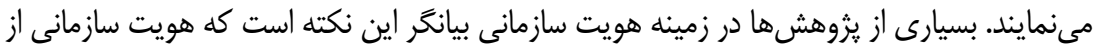

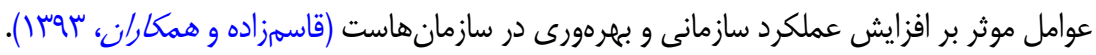

\section{حمايت سازمانى ادراككشه}

حمايت سازمانى ادراكشده به احساس مثبت ناشى از توجه سازمان به كارمند اشاره دارد. احساسى

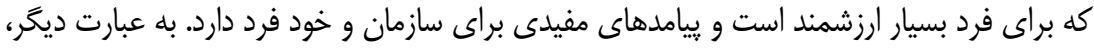

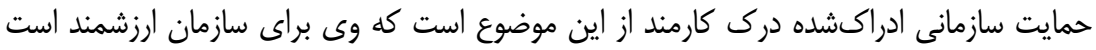

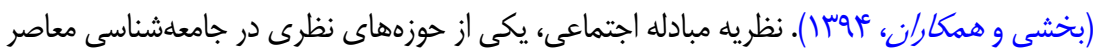

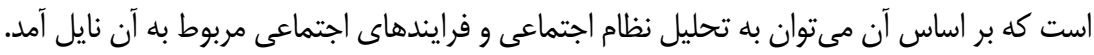

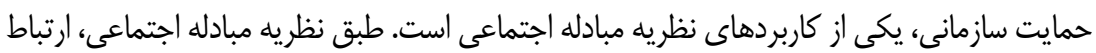
مبادلهاى بين دو طرف بلطور معمول فراتر از مبادله اقتصادى است و شامل تعاملهاى اجتماعى نيز

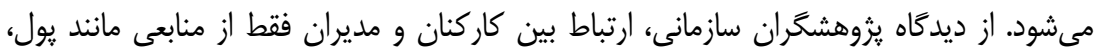

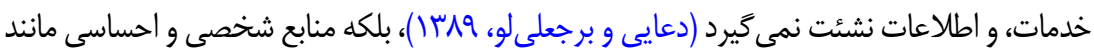

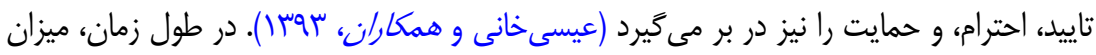
حمايتى كه سازمان از خود نشان مىدهد در كاركنان احساس الزام جبران اين حمايت رائ را ايجاد مى كند

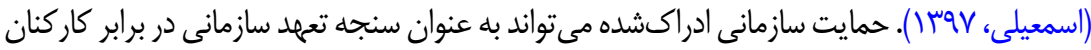
در نظر كرفته شود. درك سطح بالاى حمايت سازمانى توسط كار كنان، بيان كننده اين مطلب است كه كار كنان حمايت سازمان را در موقعيتهاى مختلف باور دارند، كه در نتيجه باعث مى شوداد كار كنان 
درصدد جبران برآيند. جنين عمل دوجانبهاى مىتواند باعث افزايش تعهد سازمانى كاركنان و دركيرى

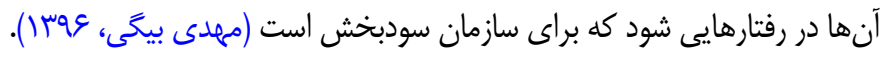

\section{تعهد عاطفى كار كنان}

تاكنون مفهوم تعهد در سه بخش شرح داده شده است: عاطفى، رفتارى، و شناختى. مولفه

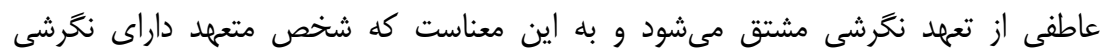

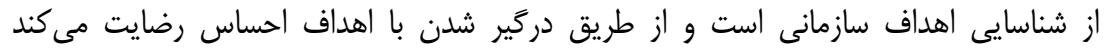

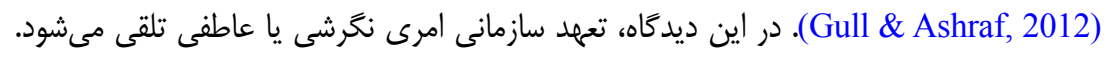

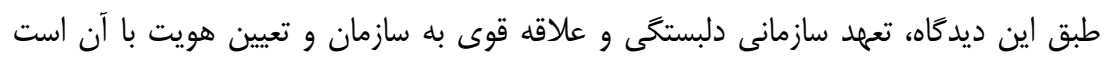

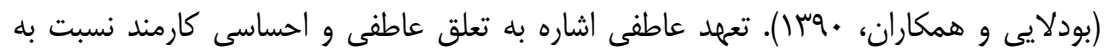

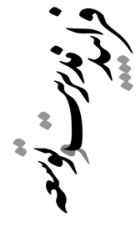
سازمان و حساسيت او به تجارب شغلى نظير حمايت سازمانى دارد. اين واكنش عاطفى به عنوان إنان هويت فردى كارمند با هويت سازمانى و احساس تعلق به سازمان توصيف مى شود، از اينرو، بسيارى

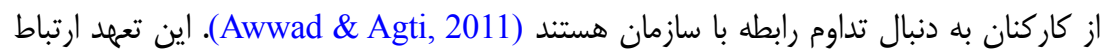

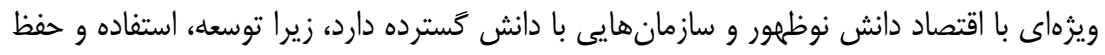
سرمايه دانش بهشدت به سطح تعهد كاركنان به سازمان مربوط وابسته است. در واقع، اين تعهاند به ايجاد حس مشترك هويت ميان افراد سازمانى و يِيدايش رفتارهاى ييشاجتماعى نظير تسهيم

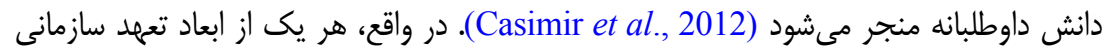
ساخت مجزايى دارد، اما اهميت تعهد عاطفى بيش از ساير ابعاد ارزيابى مىشود، زيرا بيشترين تاثير

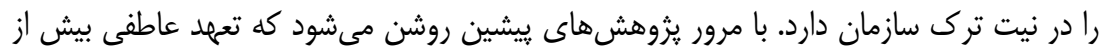

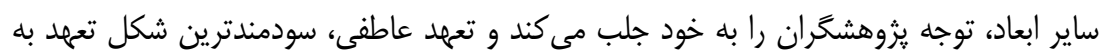

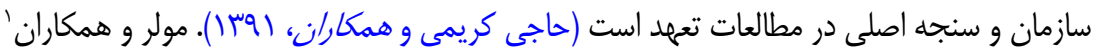

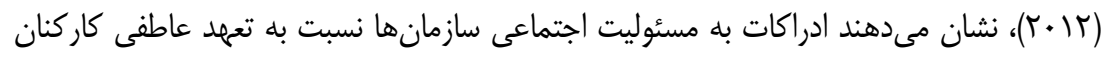

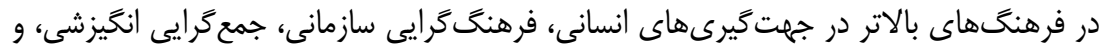

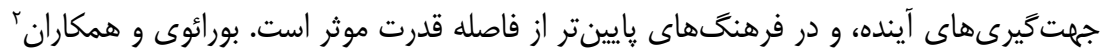
(19 (T)، نشان مىدهند بر اساس اينكه تا קه اندازه سازمان كم و بيش مسئوليت اجتماعى دارد،

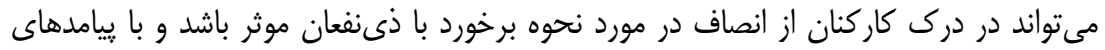

1. Mueller et al.

2. Bouraoui, et al. 
مهمى در نكَرش كاركنان و رفتار آنها در محل كار، از جمله تعهد عاطفى، همراه باشد. در

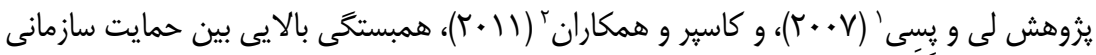

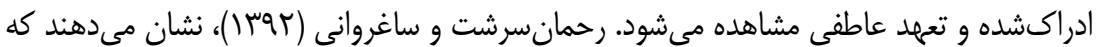
هويت سازمانى بر تعهد عاطفى اثر مثبت دارد و تعهد كاركنان را به عنوان زمينهساز مزيت رقابتى

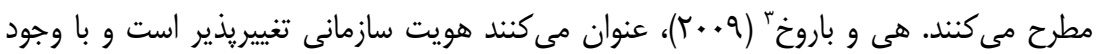

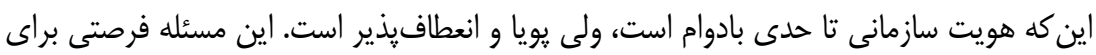
سازمان است كه هويت قوىترى ايجاد كند و تعهد عاطفى را افزايش دهد و مزيتى رقابتى فراهم آورد. همجنين، ادبيات نشان مىدهد كه هرجه تناسب افراد با سازمان بيشتر باشد، بيامدهاى شغلى مثبتتر خواهند بود، سطوح استرس كمتر، بيشتر عجين شدن با شغل، تعهد سازمانى بالاتر، نخرشهاى شغلى بهتر، نرخهاى عملكرد بالاتر، و ترك خدمت بايينتر از جمله اين يبامدها هستند (Vilela et al., 2008). بلهور كلى، تناسب فرد ـ سازمان با ييامدهاى نكرشى و رفتارى مرتبط

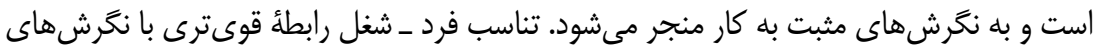

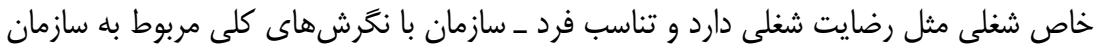

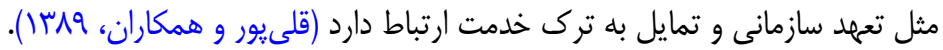

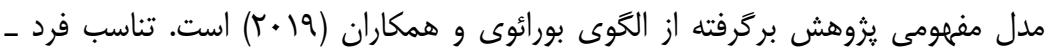
سازمان، هويت سازمانى، و حمايت سازمانى ادراكشده نقش ميانجى را در ارتباط بين مسئوليت اجتماعى سازمان و تعهد عاطفى كاركنان ايفا مى كنند (Hoffman \& Woehr, 2006).

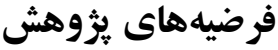

مسئوليت اجتماعى سازمان بر تناسب فرد ـ سازمان اثر مثبت و معنادار دارد. H: تناسب فرد ـ سازمان بر هويت سازمانى كار كنان اثر مثبت و معنادار دارد.

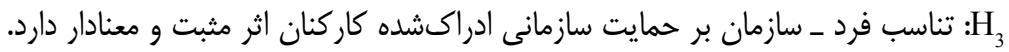
H: هويت سازمانى بر تعهد عاطفى كاركنان اثر مثبت و معنادار دارد. H: حمايت سازمانى ادراكشده بر تعهد عاطفى كاركنان اثر مثبت و معنادار دارد.

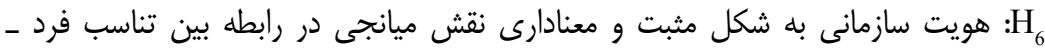
سازمان و تعهد عاطفى كاركنان دارد.

1. Lee \& Peccei

2. Casper et al.

3. He \& Baruch 
H

فرد ـ سازمان و تعهد عاطفى دارد.

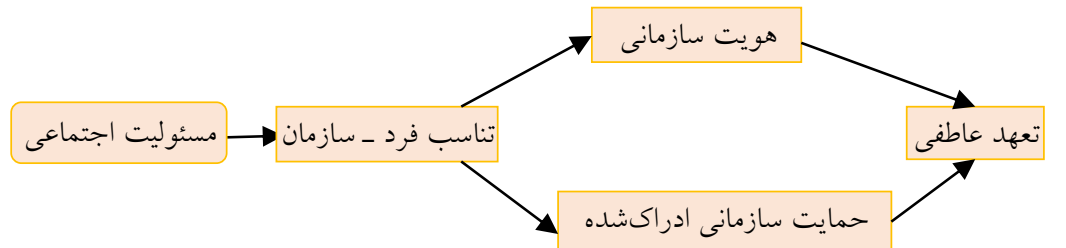

شكل 1: مدل مفهومى :ثووه (Bouraoui et al., 2019)

\section{روششناسى بزوهش}

يزوهش حاضر از نظر هدف، كاربردى و از نظر نحوه گَردآورى دادهها توصيفى است. همجنين، از

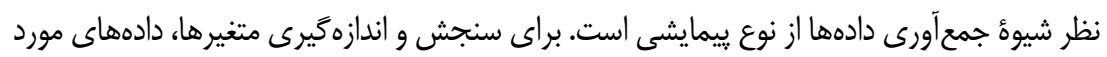
نياز از طريق برسشنامه و به صورت ميدانى از نمونههاى انتخابشده از جامعه آمارى گَردآورى شده

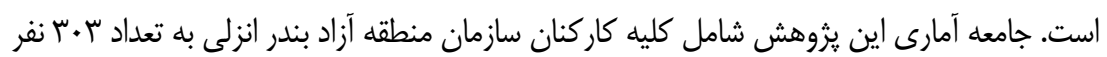
است. روش نمونهَيرى تصادفى ساده است. پايايى و اعتبار يرسشنامه توزيعشده نيز از طريق آلفاى

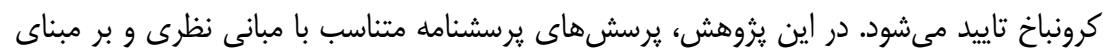

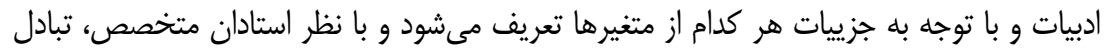
نظر و بررسى در مورد يرسشها صورت مى گيرد، و يرسشنامه اصلى بعد از مرحله تدوين به صورت

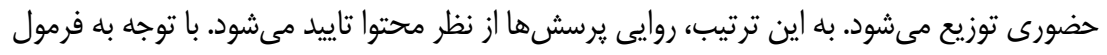

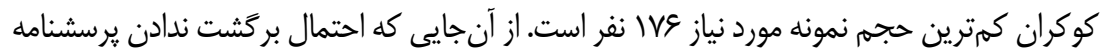

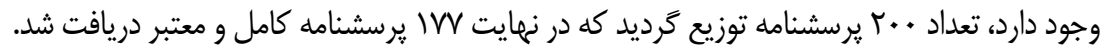

يافته هاى بزووهش

آمار جمعيتشناختى

آمارها نشان مىدهد كه VQ/V درصد پاسخدهندكان يرسشنامه از مردان و س//F درصد از

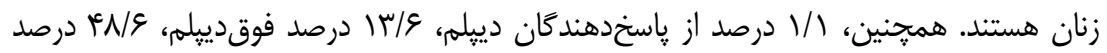


كارشناسى، و V/عץ درصد داراى تحصيلات كارشناسى ارشد و دكترى هستند.

بررسى برازش مدل يزوهش

بررسى برازش مدل در سه بخش مدل اندازهيرى، مدل ساختارى، و مدل كلى صورت

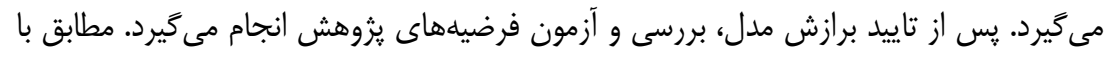

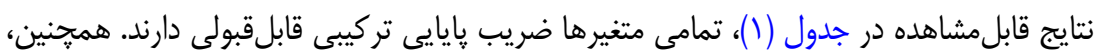
ضريب پايايى كرونباخ نيز در حد قابلقبول است. بنابراين، مىتوان نتيجه گرفت كه يرسشنامه يزوهش از يايايى مناسبى برخوردار است.

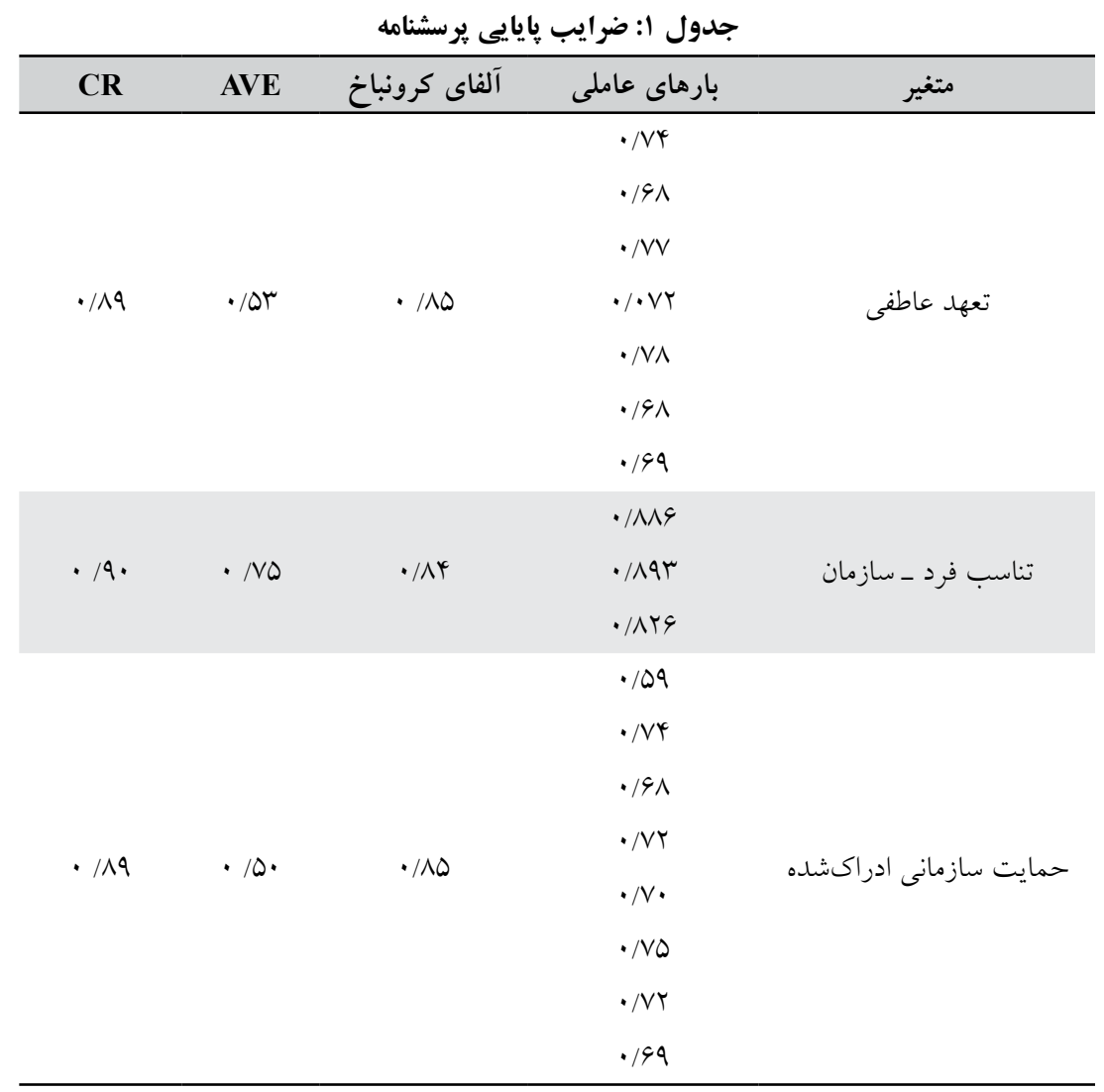


ادامه جدول ا: ضرايب پايايى برسشنامه

\begin{tabular}{|c|c|c|c|c|}
\hline CR & AVE & آلفاى كرونباخ & بارهاى عاملى & متغير \\
\hline & & & .19 & \\
\hline & & & $\cdot / 09$ & \\
\hline & & & $\cdot / v$ & \\
\hline & & & $\cdot / D F$ & \\
\hline & & &.$/ 90$ & \\
\hline & & & $\cdot|\wedge|$ & \\
\hline & & & $\cdot / V 9$ & \\
\hline & & & $\cdot / \Lambda F$ & \\
\hline \multirow[t]{12}{*}{$\cdot 194$} & $\cdot / \Delta r$ & $\cdot / 94$ & $\cdot / v \cdot$ & مسئوليت اجتماعى \\
\hline & & & $\cdot / \mathrm{V} \wedge$ & \\
\hline & & & .190 & \\
\hline & & & $\cdot / V G$ & \\
\hline & & & $\cdot / V Y$ & \\
\hline & & & $\cdot / V G$ & \\
\hline & & & $\cdot / \wedge$ & \\
\hline & & & $\cdot$ /VG & \\
\hline & & & $\cdot / V Q$ & \\
\hline & & & NQ & \\
\hline & & & $\cdot / \Lambda F$ & \\
\hline & & & $\cdot / 94$ & \\
\hline \multirow[t]{4}{*}{$\cdot \mid 11$} & $\cdot / \Delta V$ & - $/ \Lambda t$ & - & هويت سازمانى \\
\hline & & & $\cdot / \mathrm{Va}$ & \\
\hline & & & $\cdot 109$ & \\
\hline & & & $\cdot / / 9$ & \\
\hline
\end{tabular}

همانطور كه مشخص است، تمامى گويهها داراى بار عاملى مناسب (بالاتر از ه/•) هستند

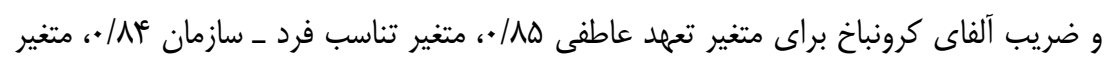

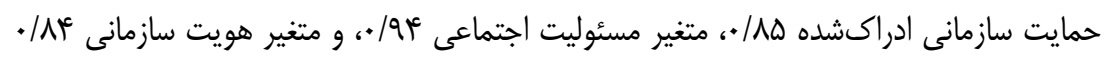
است. مقدار AVE براى تمامى سازههاى مدل مقدار استاندارد ه/ • بهدست آمده است، در نتيجه روايى همخراى مدل و برازش مدلهاى اندازهيرى تاييد مىشود. 
آزمون فرضيهها

جدول r: نتايج تحليل آزمون فرضيههاى ثزوهش

\begin{tabular}{|c|c|c|c|c|c|}
\hline نتيجه & ضريب مسير & T-Value & & 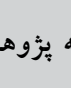 & فرضيه \\
\hline تاييد & $\cdot / 119$ & TV/ar. & ادراى از تناسب فرد ـ سازمان & $\leftarrow$ & ادراى از مسئوليت اجتماعى \\
\hline تاييد & •/va. & $T M / Q K H$ & هويت سازمانى كاركنان & $\leftarrow$ & H ادراك از تناسب فرد ـ سازمان \\
\hline تاييد & $\cdot 19 \cdot r$ & $9 / 944$ & حمايت سازمانى ادراكشده & $\leftarrow$ & H ادراك از تناسب فرد ــ سازمان \\
\hline تاييد & $\cdot / 4 \mid f$ & $V / T 19$ & تعهد عاطفى & $\leftarrow$ & ل هويت سازمانى \\
\hline تاييد & $\cdot / 490$ & $9 / 4 \cdot 9$ & تعهد عاطفى & $\leftarrow$ & حمايت سازمانى ادراكشده H $_{5}$ \\
\hline
\end{tabular}

جدول ب: نتايج آزمون فرضيههاى ميانجى

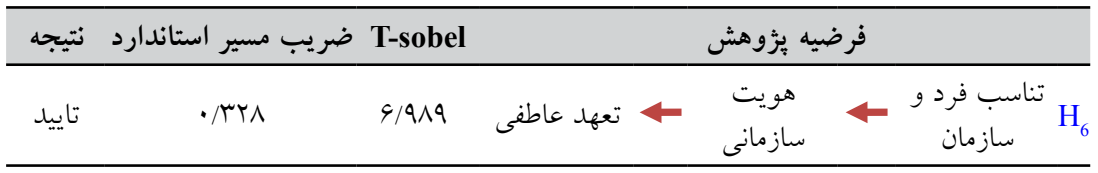

\begin{tabular}{|c|c|c|c|}
\hline \multicolumn{4}{|c|}{ جدول †ٔ نتايج تحليل آزمون فرضيههاى ميانجى } \\
\hline نتيجه & ضريب مسير استاندارد & T-Sobel & فرضيه بُروهش \\
\hline تاييد & $\cdot / T \wedge \cdot$ & $9 / \sqrt{90}$ & 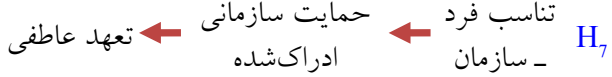 \\
\hline
\end{tabular}

با توجه به جدول (T)، مشاهده مىشود كه ميزان آماره t بين دو متغير ادراك از مسئوليت

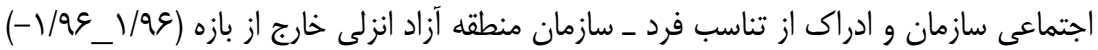

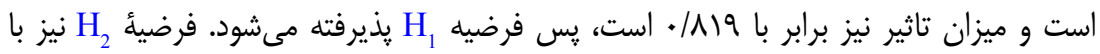

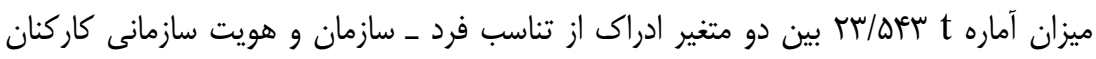

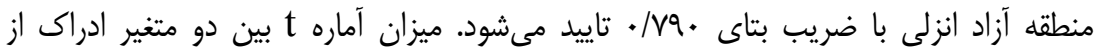

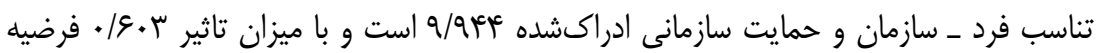

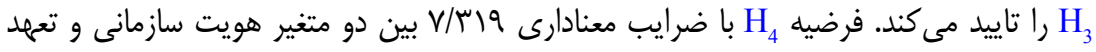

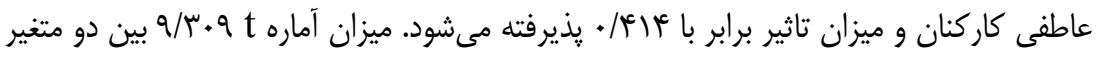
حمايت سازمانى ادراكشده و تعهد عاطفى كاركنان با ضريب تاثير هوء/. فرضيه H H را به لحاظ 
آمارى قبول مى كند. در مورد متغيرهاى ميانجى نيز مشاهده مىشود كه ميزان رابطه تناسب فرد

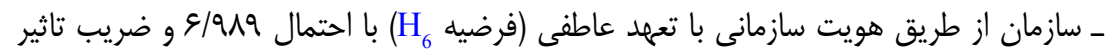

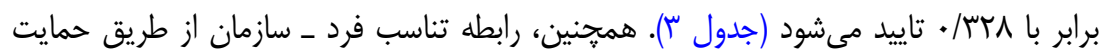

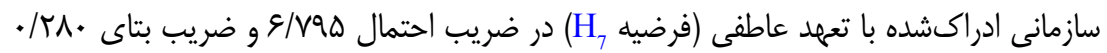

$$
\text { تاييد مى شود (جدول عاز). }
$$

برازش مدل كلى بر اساس معيار GOF بررسى مىشود. با توجه به ميانكين مقادير اشتراكى

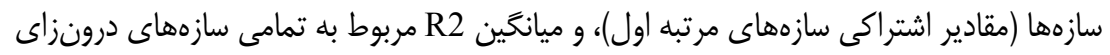
مدل، مقدار GOF براى برازش كلى مدل بزوهش حاضر برابر است با:

GOF $=\sqrt{\overline{\text { Communalitles }} \times \overline{R^{2}}}=\sqrt{0.576 \times 0.578}=0.577$

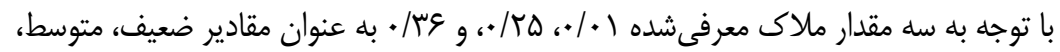

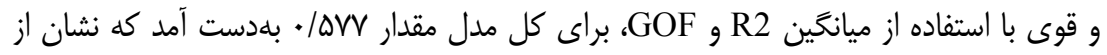

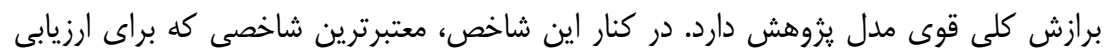

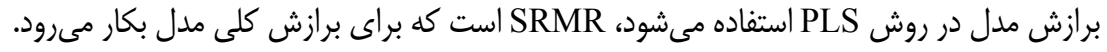

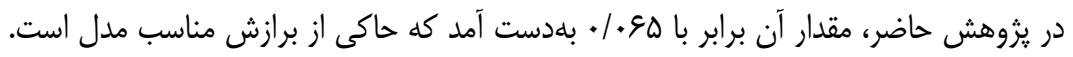

\section{بحث و نتيجه كيرى}

هدف يزوهش حاضر، بررسى تاثير مسئوليت اجتماعى دركشده بر تعهد عاطفى كاركنان با توجه به نقش ميانجى تناسب فرد ـ سازمان، هويت سازمانى، و حمايت سازمانى ادراكشده است.

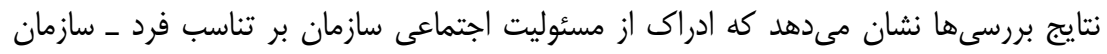

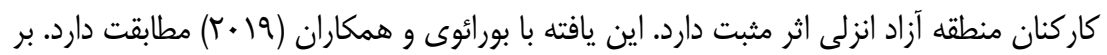

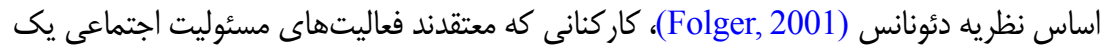
وظيفه اخلاقى سازمانى است و مطابق با اخلاق و هنجارهاى عدالت اجرا مىشود، براى عدالت در فعاليتهاى مسئوليت اجتماعى مراقبت مى كنند، زيرا معتقدند اين يكى تعهد اخلاقى است. تاثير

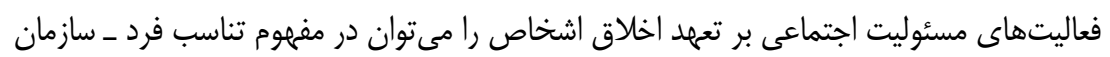
در نظر ترفت (Bouraoui et al., 2019). نتايج ما نشان مىدهد كه ادراك از تناسب فرد ـ سازمان بر هويت سازمانى كاركنان منطقه

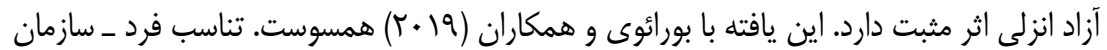

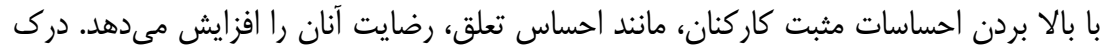


از تناسب با سازمان خودينداره فرد را ارتقا مىدهد و به نوبه خود هويت سازمانى را بهبود مىبخشد

.(Bouraoui et al., 2019)

نتايج فرضيهها بيان مى كند كه ادراك از تناسب فرد ـ سازمان بر حمايت سازمانى ادراكشده

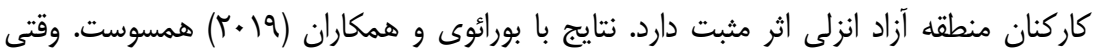

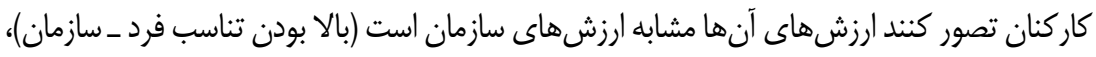

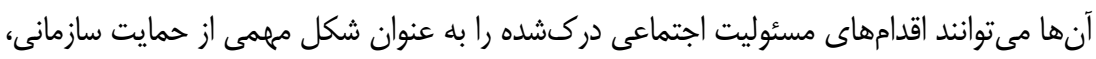
كه در برآوردن نيازهاى اساسىشان نقش دارد، در نظر بخيرند (Bouraoui et al., 2019).

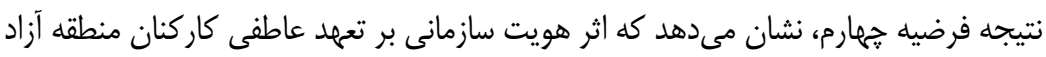

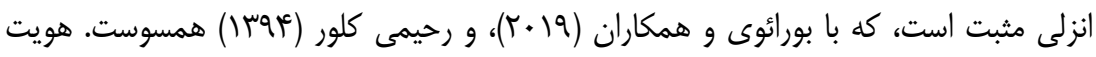

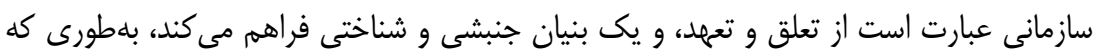

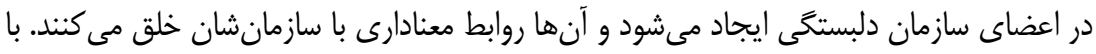

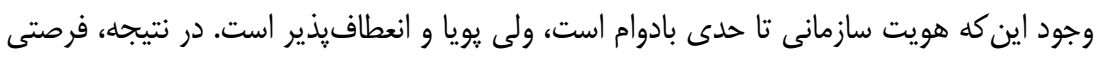

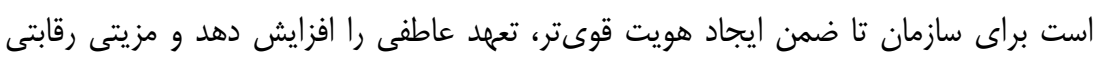

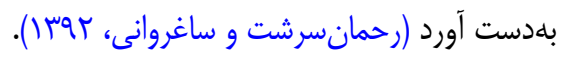

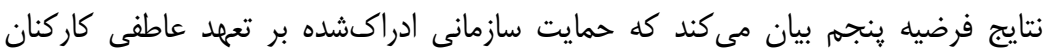

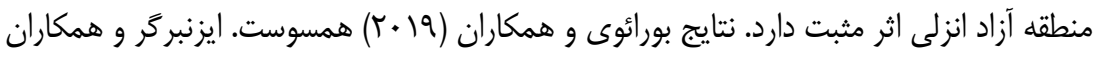

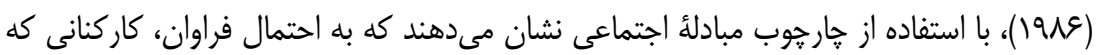
سطوح بالايى از حمايت سازمانى را ادراك مى كنند، احساس تكليف بيشترى در جبران إنان حمايت

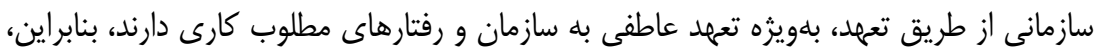

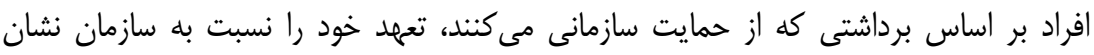

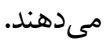

نتايج تحليلها نشان مىدهد كه هويت سازمانى در تناسب فرد ـ سازمان بر تعهد عاطفى كاركنان

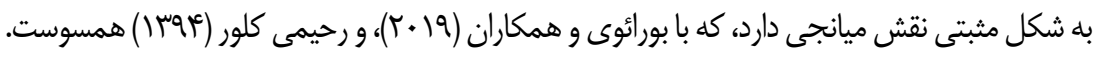

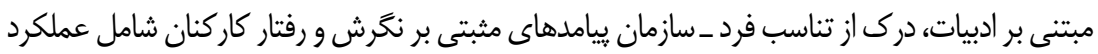

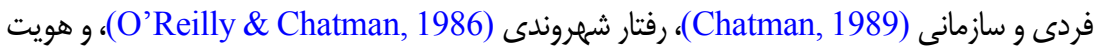

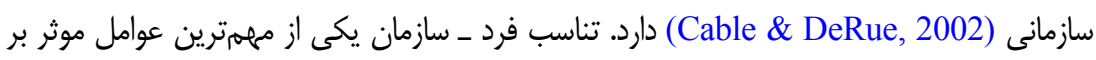

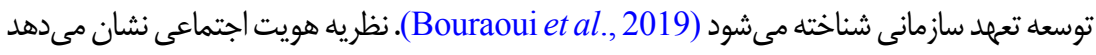

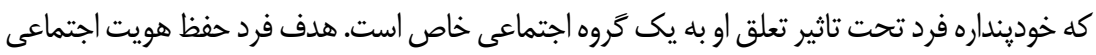


مثبت است. بنابراين، در حضور سطوح بايين از شناسايى با يك كروه خاص فرد بهاحتمال مى تواند كروه

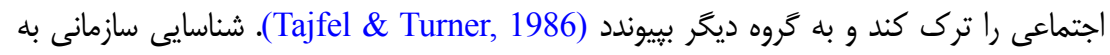

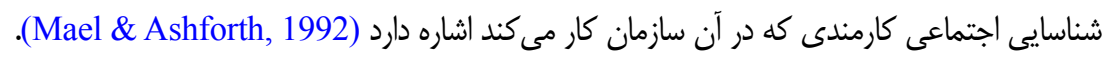

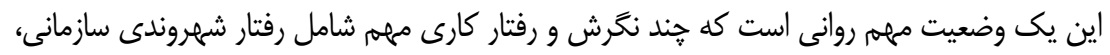

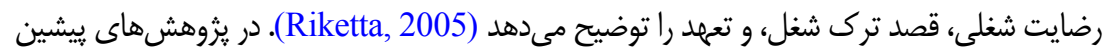
تناسب فرد ـ سازمان با بالا رفتن احساسات مثبت، مانند احساس تعلق، سبب بالا رفتن رضايت شغلى

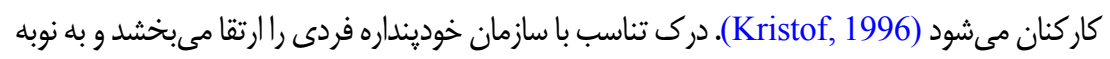

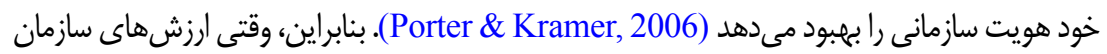

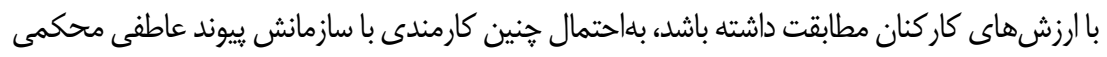
برقرار مى كند. يافتهاى ما نشان مىدهد كه حمايت سازمانى ادراكشده در تناسب فرد ـ سازمان بر

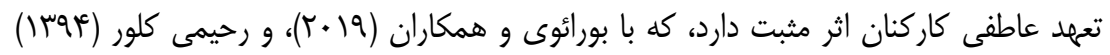

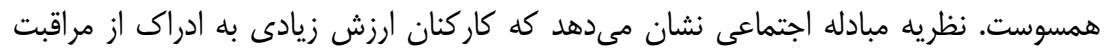

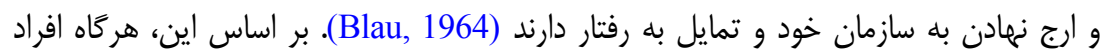

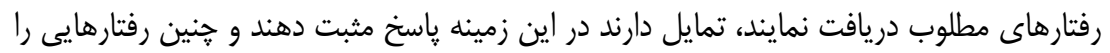

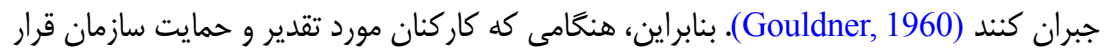
كيرند، احساس مى كنند كه مديون ياسخ مثبت هستند. اين احساس نهفقط به معناى تعهد سخت كاند كارى به منظور دستيابى به اهداف سازمانى است، بلكه در يك تعهد عاطفى بيشتر و تمايل قوى ماتر

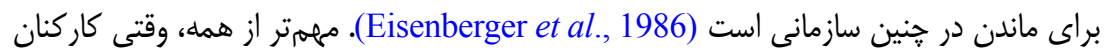
عدالت و رفتارهاى اخلاقى اتخاذشده را بالا ارزيابى كنند، ممكن است حمايت سازمانى بيشترى از سازمان براى انجام تعهدهاى اخلاقى درك نمايند (Turker, 2009). كاركنانى كه ارزشهاى

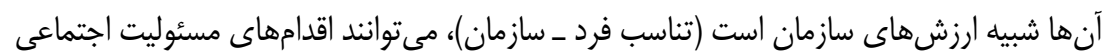

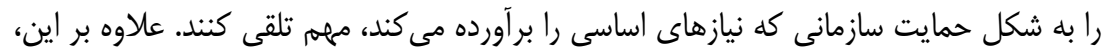

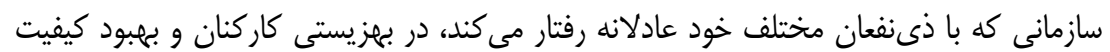
محيط كار آنها نقش دارد (Eisenberger et al., 1986).

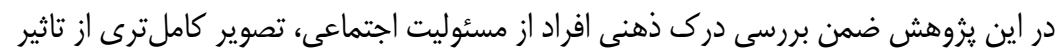

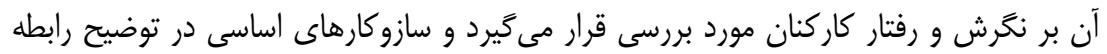

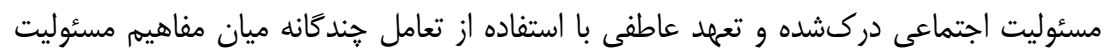


اجتماعى، حمايت سازمانى ادراكشده، هويت سازمانى، تعهد عاطفى، و تناسب فرد ـ سازمان

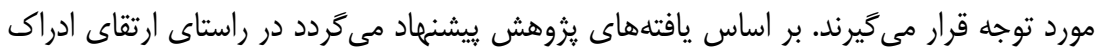

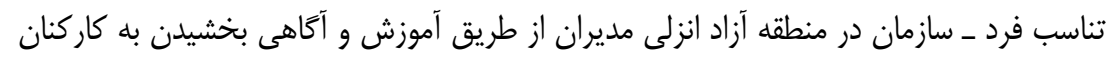

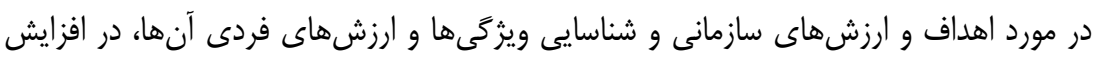

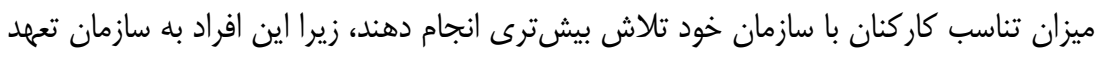

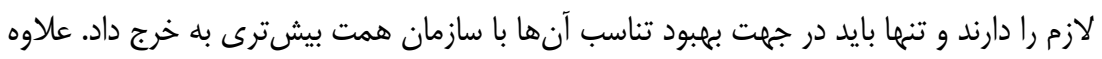

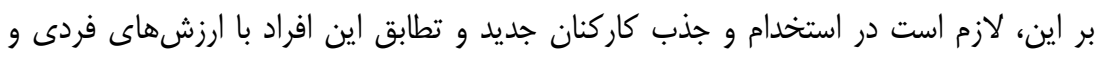

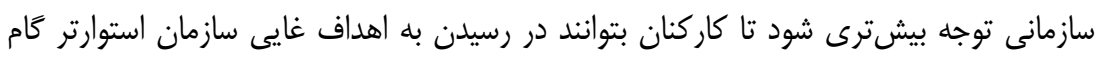

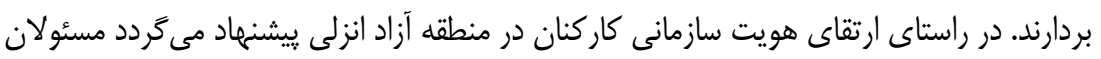

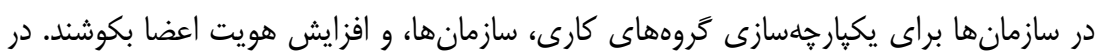

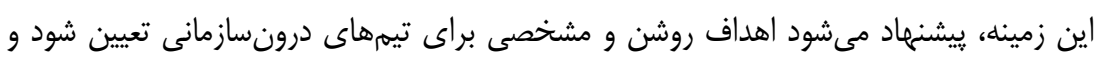

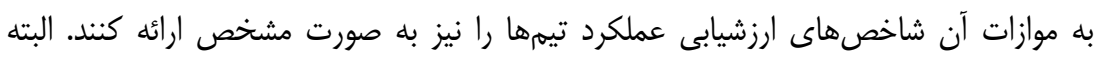

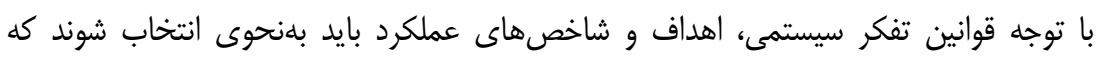

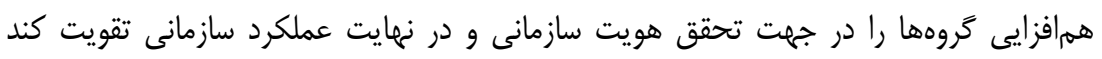

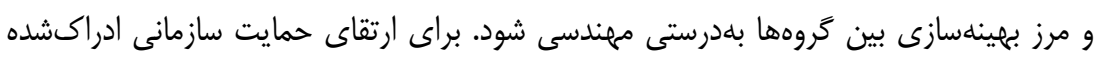

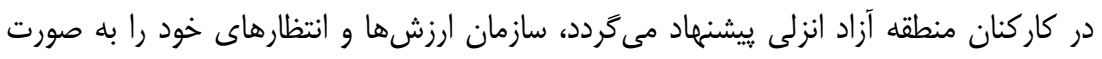

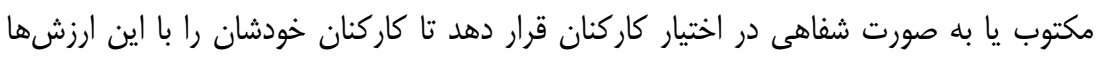

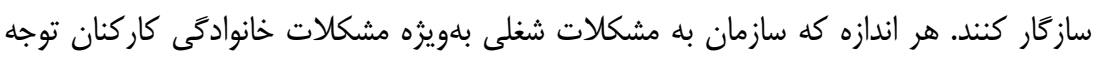

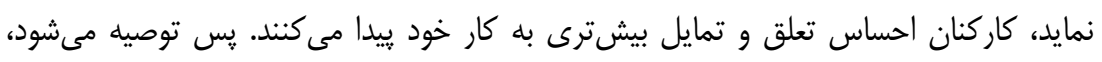

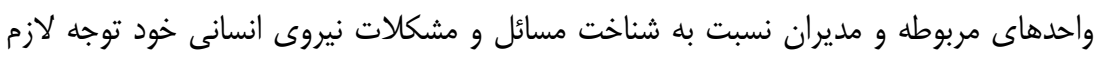

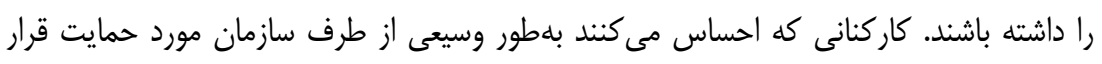

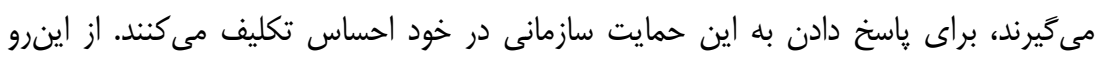

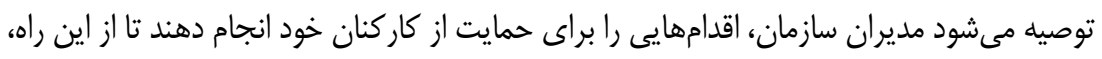

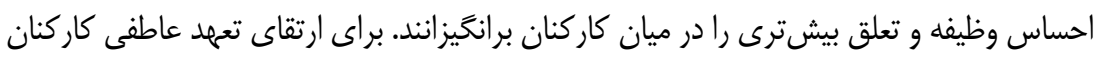

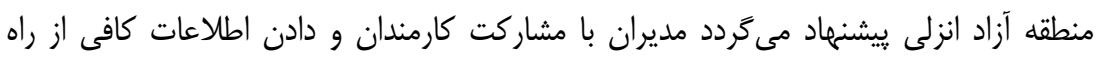

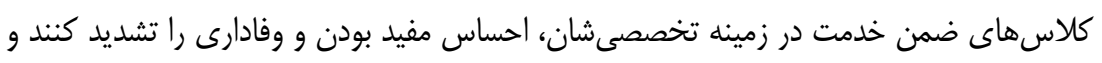

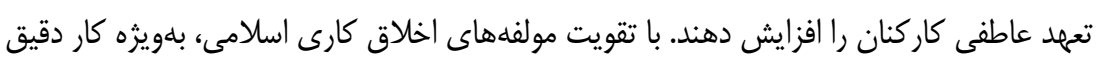

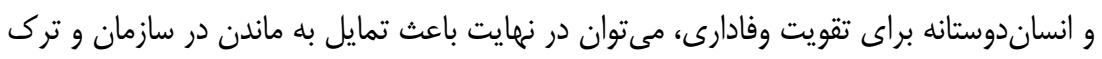


نكردن شغل شد. شناسايى عوامل ايجادكننده ناهمسانى و اقدام به از بين بردن آنها باعث ايجاد

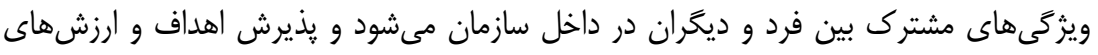

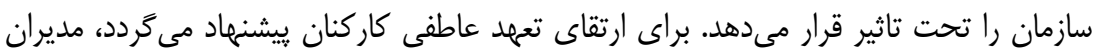

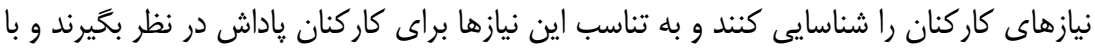

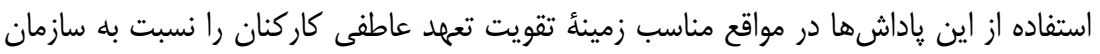
فراهم آورند. به مديران كل منطقه آزاد بندر انزلى ييشنهاد مىشود، هنكام استخدام نيروى انسانى،

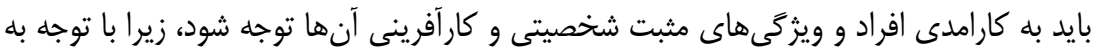

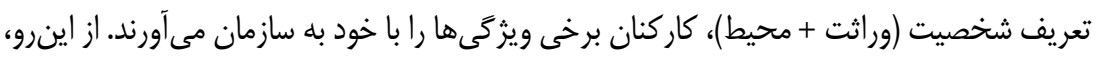

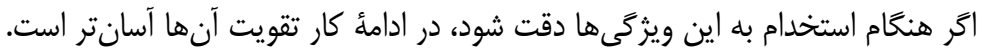

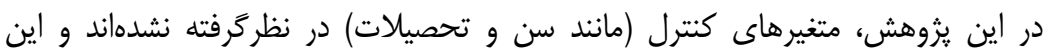
موضوع مىتواند نتايج را تحت تاثير قرار دهد. با توجه به اين كه نخاه و اهداف كار كنان منطقه آزاد انزلى (با توجه به جنسيت، سن، تحصيلات و سابقه همكارى كار كنان با سازمان) متفاوت است،

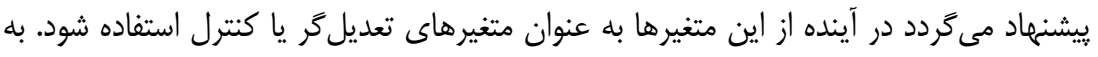

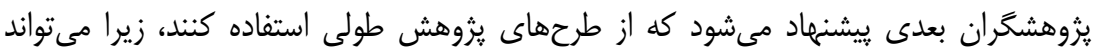

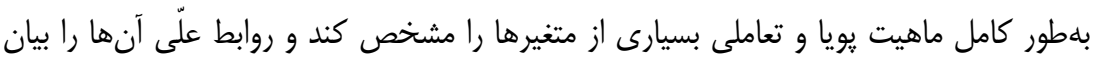
نمايد. همجنين، يِشنهاد مىشود تاثير ساير متغيرهاى ميانجى مانند فرهنگ سازمانى و سرمايه روانشناختى در رابطه بين مسئوليت اجتماعى و تعهد عاطفى مورد بررسى قرار كيرد.

منابع

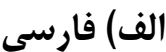

اردلان، محمدرضا؛ قنبرى، سيروس؛ بهشتىراد، رقيه، و نويدى، يرويز (أوسار). تاثير سرمايه اجتماعى و

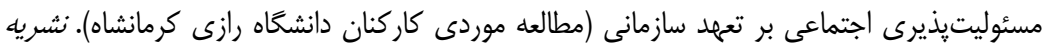

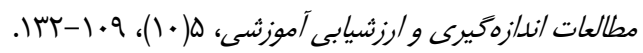

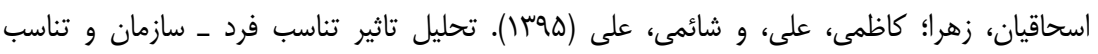

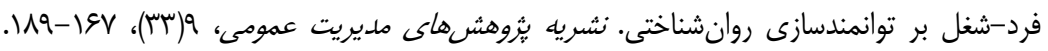

10.22111/jmr.2016.2854

اسمعيلى، محمد (Vوسا). تبيين رابطه حمايت سازمانى ادراكشده و رفتار شهروندى سازمانى. نشريه

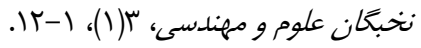


آزور، هيوا، و كاظمى، مهدى (سوسب). شناسايى تاثير مسئوليت اجتماعى سازمان بر كيفيت روابط كار كنان

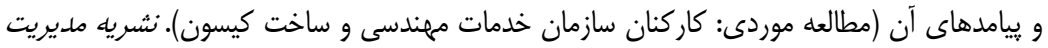

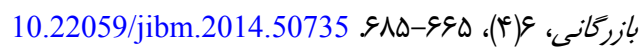

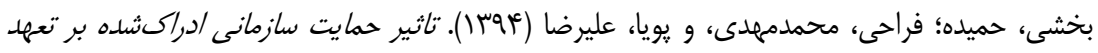

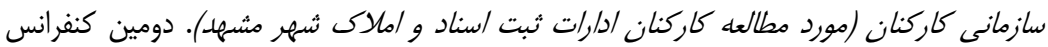

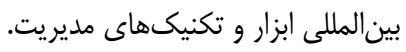

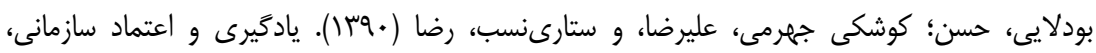

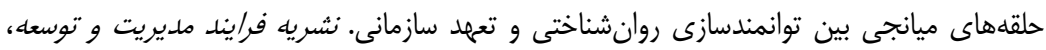

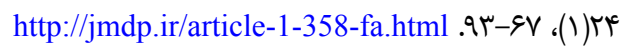

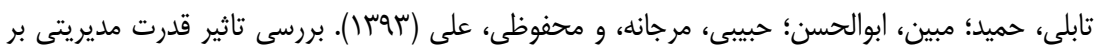

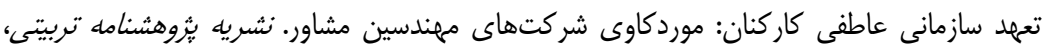
(1)

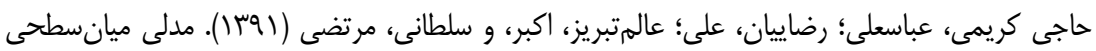

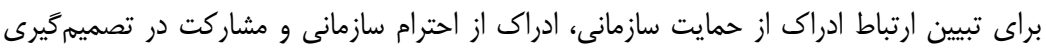

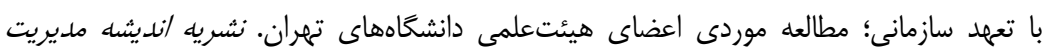

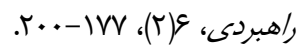

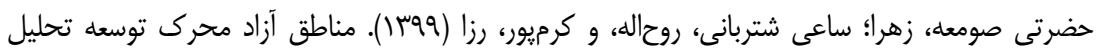

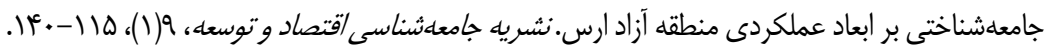

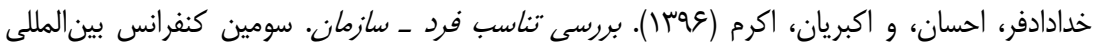

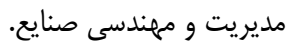

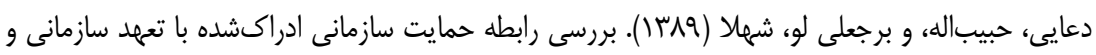

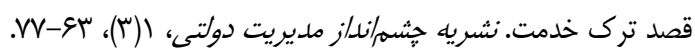

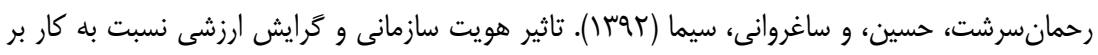

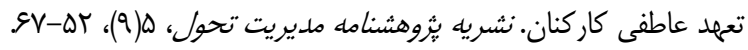

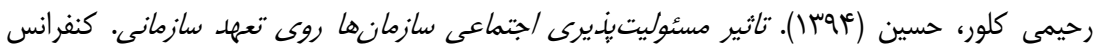

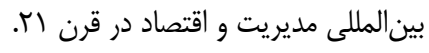

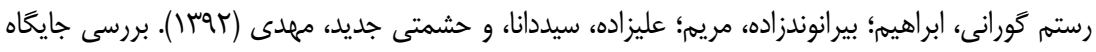

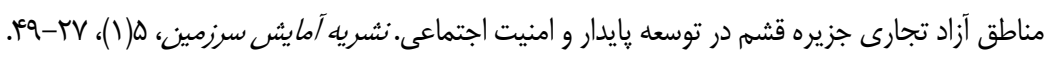

10.22059/jtcp.2013.35470

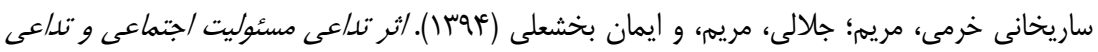

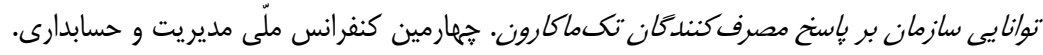

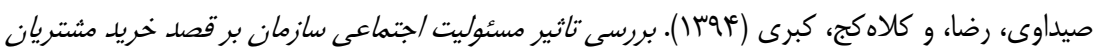

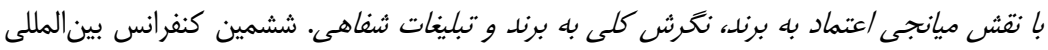




$$
\text { اقتصاد، مديريت و علوم مهندسى. }
$$

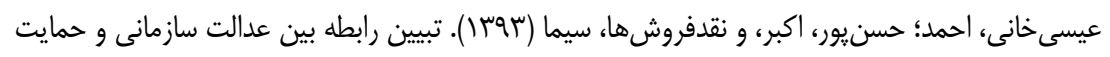

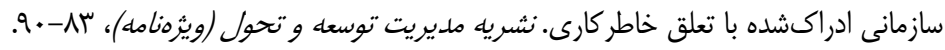

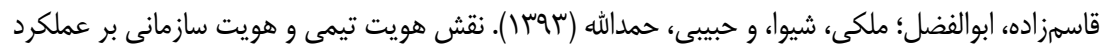

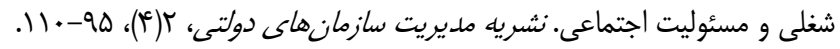

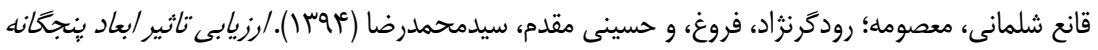

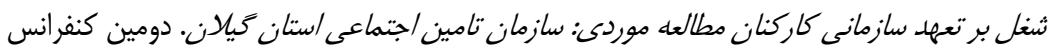

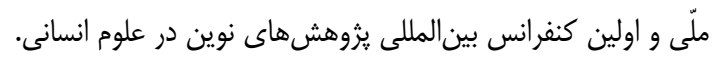

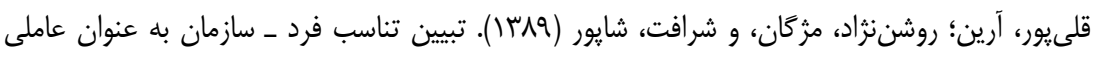

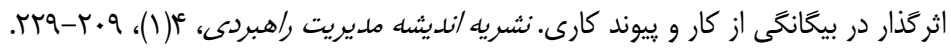

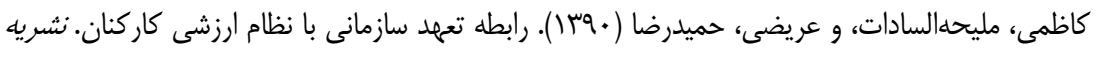

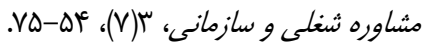

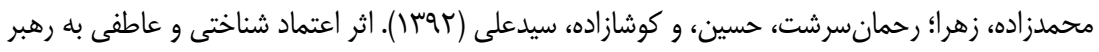

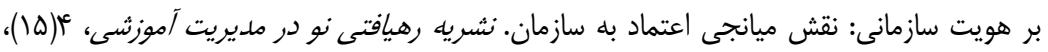

$$
\text { r. }
$$

محمدنزاد فدردى، منصوره؛ حميدىزاده، على، و باباشاهى، جبار (هوسا). تاثير نشان كارفرما بر نكخهداشت

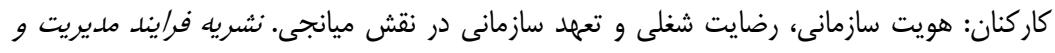

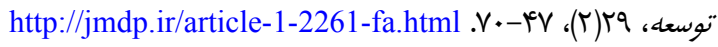

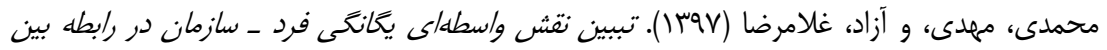

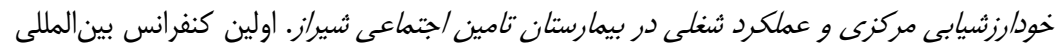

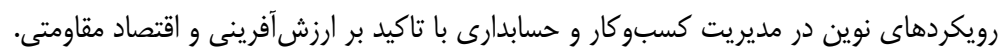

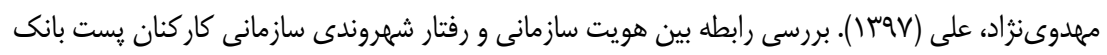

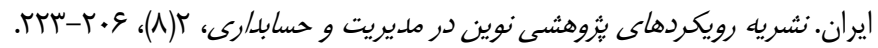

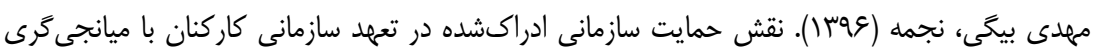

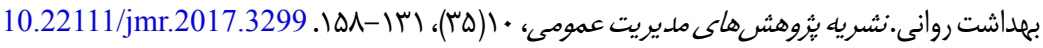

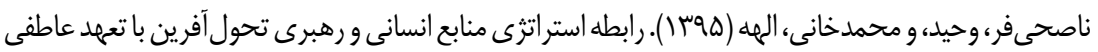

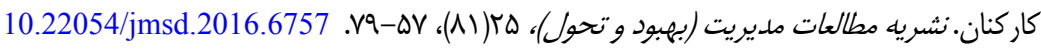

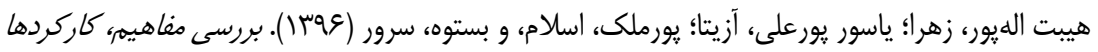

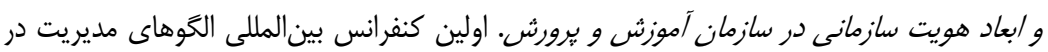
عصر ييشرفت.

Aguinis, H., \& Glavas, A. (2012). What We Know and Don't Know About 
Corporate Social Responsibility: A Review and Research Agenda. Journal of Management, 38(4), 932-968. https://doi.org/10.1177/0149206311436079.

Ahmad, R., Ahmad, S., Islam, T., \& Kaleem, A. (2020). The Nexus of Corporate Social Responsibility (CSR), Affective Commitment and Organisational Citizenship Behaviour in Academia. Employee Relations: The International Journal, 42(1), 232-247. https://doi.org/10.1108/ER-04-2018-0105.

Alniaçik, E., Alniaçik, Ü., Erat, S., \& Akçin, K. (2013). Does Person-Organization Fit Moderate the Effects of Affective Commitment and Job Satisfaction on Turnover Intentions? Procedia-Social and Behavioral Sciences, 99(1), 274-281. https://doi.org/10.1016/j.sbspro.2013.10.495.

Ashforth,B.E., \& Mael,F.(1989). Social Identity Theory and the Organization. Academy of Management Review, 14(1), 20-39. https://doi.org/10.5465/amr.1989.4278999.

Awwad, M. S., \& Agti, D. A. M. (2011). The Impact of Internal Marketing on Commercial Banks' Market Orientation. International Journal of Bank Marketing, 29(4), 308-332. https://doi.org/10.1108/02652321111145943.

Blau, P. (1964). Power and Exchange in Social Life: John Wiley \& Sons.

Bouraoui, K., Bensemmane, S., Ohana, M., \& Russo, M. (2019). Corporate Social Responsibility and Employees' Affective Commitment. Management Decision, 57(1), 152-167. https://doi.org/10.1108/MD-10-2017-1015.

Cable, D. M., \& DeRue, D. S. (2002). The Convergent and Discriminant Validity of Subjective Fit Perceptions. Journal of Applied Psychology, 87(5), 875-884. https://doi.org/10.1037/0021-9010.87.5.875.

Casimir, G., Lee, K., \& Loon, M. (2012). Knowledge Sharing: Influences of Trust, Commitment and Cost. Journal of Knowledge Management, 16(5), 740-753. https://doi.org/10.1108/13673271211262781.

Casper, W. J., Harris, C., Taylor-Bianco, A., \& Wayne, J. H. (2011). WorkFamily Conflict, Perceived Supervisor Support and Organizational Commitment among Brazilian Professionals. Journal of Vocational Behavior, 79(3), 640-652. https://doi.org/10.1016/j.jvb.2011.04.011.

Chatman, J. A. (1989). Improving Interactional Organizational Research: A Model of Person-Organization Fit. Academy of Management Review, 14(3), 333-349. https://doi.org/10.5465/amr.1989.4279063.

Cheema, S., Afsar, B., \& Javed, F. (2020). Employees' Corporate Social Responsibility Perceptions and Organizational Citizenship Behaviors for the Environment: The Mediating Roles of Organizational Identification and Environmental Orientation Fit. Corporate Social Responsibility and Environmental Management, 27(1), 9-21. https://doi.org/10.1002/csr.1769.

DeConinck, J. B. (2010). The Effect of Organizational Justice, Perceived Organizational Support, and Perceived Supervisor Support on Marketing 
Employees' Level of Trust. Journal of Business Research, 63(12), 13491355. https://doi.org/10.1016/j.jbusres.2010.01.003.

Eisenberger, R., Huntington, R., Hutchison, S., \& Sowa, D. (1986). Perceived Organizational Support. Journal of Applied Psychology, 71(3), 500-507. https://doi.org/10.1037/0021-9010.71.3.500.

Farooq, O., Rupp, D. E., \& Farooq, M. (2017). The Multiple Pathways through

Which Internal and External Corporate Social Responsibility Influence Organizational Identification and Multifoci Outcomes: The Moderating Role of Cultural and Social Orientations. Academy of Management Journal, 60(3), 954-985. https://doi.org/10.5465/amj.2014.0849.

Folger, R. (2001), Fairness as Deonance, in Gilliland, S.W., Steiner, D.D. and

Skarlicki, D.P. (Eds), Research in Social Issues in Management, Information Age Publishers.

Gallardo-Vázquez, D., \& Sanchez-Hernandez, M. I. (2014). Measuring Corporate Social Responsibility for Competitive Success at a Regional Level. Journal of Cleaner Production, 72(1), 14-22. https://doi.org/10.1016/j.jclepro.2014.02.051.

Gouldner, A. W. (1960). The Norm of Reciprocity: A Preliminary Statement. American Sociological Review, 25(2), 161-178. https://doi.org/10.2307/2092623.

Gull, S., \& Ashraf, S. M. (2012). Impact of Internal Branding on Service Employees' Quality Commitment-Study on Education Sector of Pakistan. International Journal of Business and Social Science, 3(14), 814-830.

He, H., \& Baruch, Y. (2009). Transforming Organizational Identity under Institutional Change. Journal of Organizational Change Management, 22(6), 575-599. https://doi.org/10.1108/09534810910997014.

Hoffman, B. J., \& Woehr, D. J. (2006). A Quantitative Review of the Relationship between Person-Organization Fit and Behavioral Outcomes. Journal of Vocational Behavior, 68(3), 389-399. https://doi.org/10.1016/j.jvb.2005.08.003.

Huang, F.-H., Ye, Y.-J., \& Kao, C.-H. (2015). Developing a Novel Intuitionistic Fuzzy Importance-Performance Analysis for Evaluating Corporate Social Responsibility in Sport Tourism Event. Expert Systems with Applications, 42(19), 6530-6538.

Kristof, A. L. (1996). Person-Organization Fit: An Integrative Review of Its Conceptualizations, Measurement, and Implications. Personnel Psychology, 49(1), 1-49. https://doi.org/10.1111/j.1744-6570.1996.tb01790.x.

Lee, J., \& Peccei, R. (2007). Perceived Organizational Support and Affective Commitment: The Mediating Role of Organization-Based Self-Esteem in the Context of Job Insecurity. Journal of Organizational Behavior: The International Journal of Industrial, Occupational and Organizational 
Psychology and Behavior, 28(6), 661-685. https://doi.org/10.1002/job.431. Mael, F., \& Ashforth, B. E. (1992). Alumni and Their Alma Matter: A Partial Test of the Reformulated Model of Organizational Identification. Journal of Organizational Behavior, 13(2), 103-123. https://doi.org/10.1002/job.4030130202.

Mueller, K., Hattrup, K., Spiess, S.-O., \& Lin-Hi, N. (2012). The Effects of Corporate Social Responsibility on Employees' Affective Commitment: A Cross-Cultural Investigation. Journal of Applied Psychology, 97(6), 11861200. https://doi.org/10.1037/a0030204.

O'Reilly, C. A., \& Chatman, J. (1986). Organizational Commitment and Psychological Attachment: The Effects of Compliance, Identification, and Internalization on Prosocial Behavior. Journal of Applied Psychology, 71(3), 492-499. https://doi.org/10.1037/0021-9010.71.3.492.

Porter, M. E., \& Kramer, M. R. (2006). The Link between Competitive Advantage and Corporate Social Responsibility. Harvard Business Review, 84(12), 78-92.

Riketta, M. (2005). Organizational Identification: A Meta-Analysis. Journal of Vocational Behavior, 66(2), 358-384. https://doi.org/10.1016/j.jvb.2004.05.005. Schneider, B. (1987). The People Make the Place. Personnel Psychology, 40(3), 437-453.

Setiawan, M., \& Darmawan. (2011). The Relationship between Corporate Social Responsibility and Firm Financial Performance: Evidence from the Firms Listed in LQ45 of the Indonesian Stock Exchange Market. European Journal of Social Sciences, 23(1), 288-293.

Story, J. S., \& Castanheira, F. (2019). Corporate Social Responsibility and Employee Performance: Mediation Role of Job Satisfaction and Affective Commitment. Corporate Social Responsibility and Environmental Management, 26(6), 1361-1370. https://doi.org/10.1002/csr.1752.

Tajfel, H. \& Turner, J. C. (1986). The Social Identity Theory of Intergroup Behavior, in Worchel, S. and Austin, W.G. (Eds), Psychology of Intergroup Relations, Nelson-Hall.

Turker, D. (2009). Measuring Corporate Social Responsibility: A Scale Development Study. Journal of Business Ethics, 85(4), 411-427. https://doi.org/10.1007/s10551-008-9780-6.

Vilela, B. B., González, J. A. V., \& Ferrín, P. F. (2008). Person-Organization Fit, OCB and Performance Appraisal: Evidence from Matched SupervisorSalesperson Data Set in a Spanish Context. Industrial Marketing Management, 37(8), 1005-1019. 


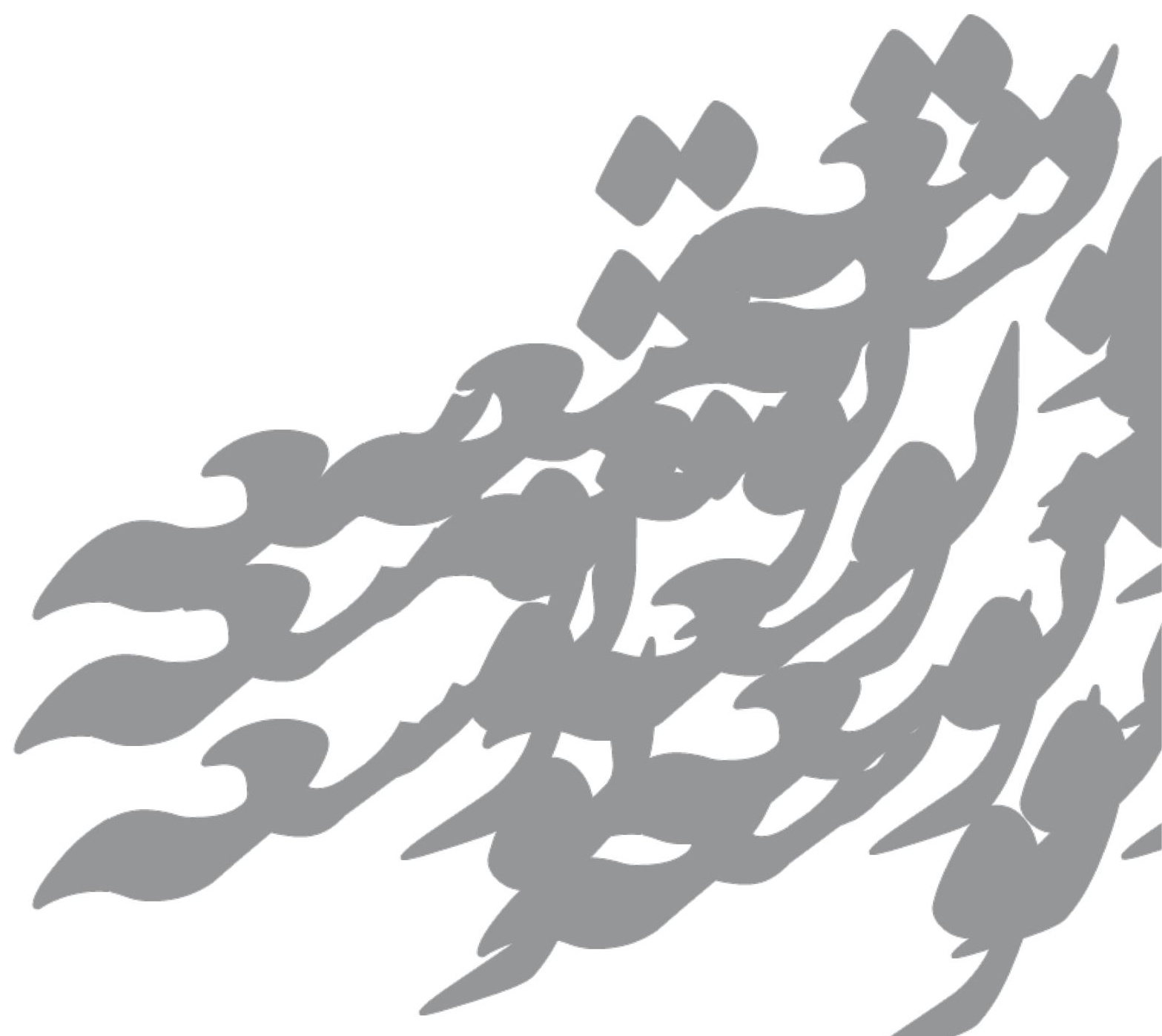

